البصيرة: مجلة الاراسات الإسلامية

AL-BASHIRAH: JOURNAL OF ISLAMIC STUDIES

Vol. 2 No. 2 (2020): 186-206

ISSN: $2807-2170$

Website: https://journal.stiba.ac.id

\title{
حكم تعزير مانع الزكاة بأخذ المال عند المذاهب الأربعة
}

\author{
مكران عثمان \\ المعهد العالي للدراسات الإسلامية واللغة العريبة بمكسر \\ البريد الإلكتروين : mukran@stiba.ac.id \\ عمران بخارى \\ المعهد العالي للدراسات الإسلامية واللغة العريبة بمكسر \\ aboeabduh@gmail.com : البريد الإلكتروني \\ أول رفاعي وهاب \\ المعهد العالي للدراسات الإسلامية واللغة العريبة بمكسر

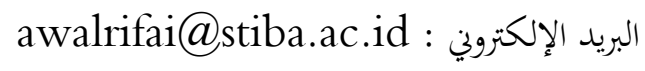 \\ أريس فردوس \\ المعهد العالي للدراسات الإسلامية واللغة العريبة بمكسر \\ arisfirdaus@gmail.com : البريد الإلكترونية
}

\section{المستخلص}

الزكاة فرض عين على كل من توفرت فيه شروط وجوبها، وقد ثبتت فرضيتها بالكتاب والسنة والإجماع، وفرضها معلوم

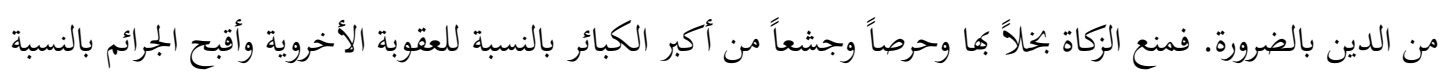

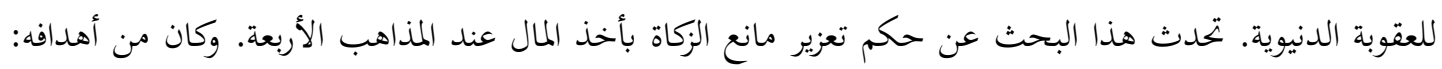

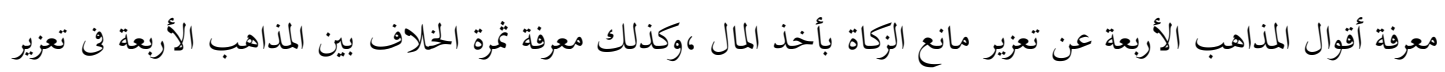
مانع الزكاة بأخذ المال. المنهج العلمي الذي سار عليه الباحث للوصول إلى النتائج هو المنهج الاستقرائي والمنهج المقارن

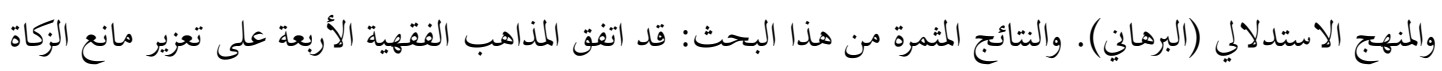

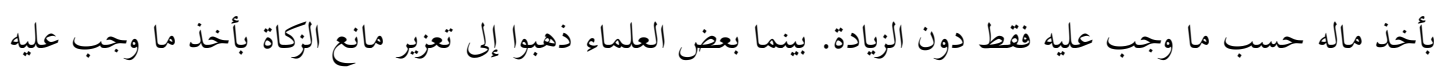

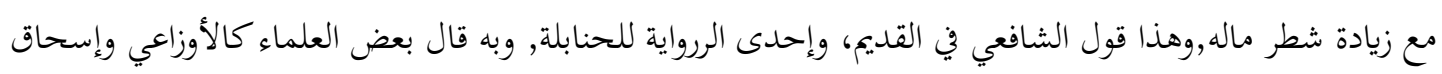




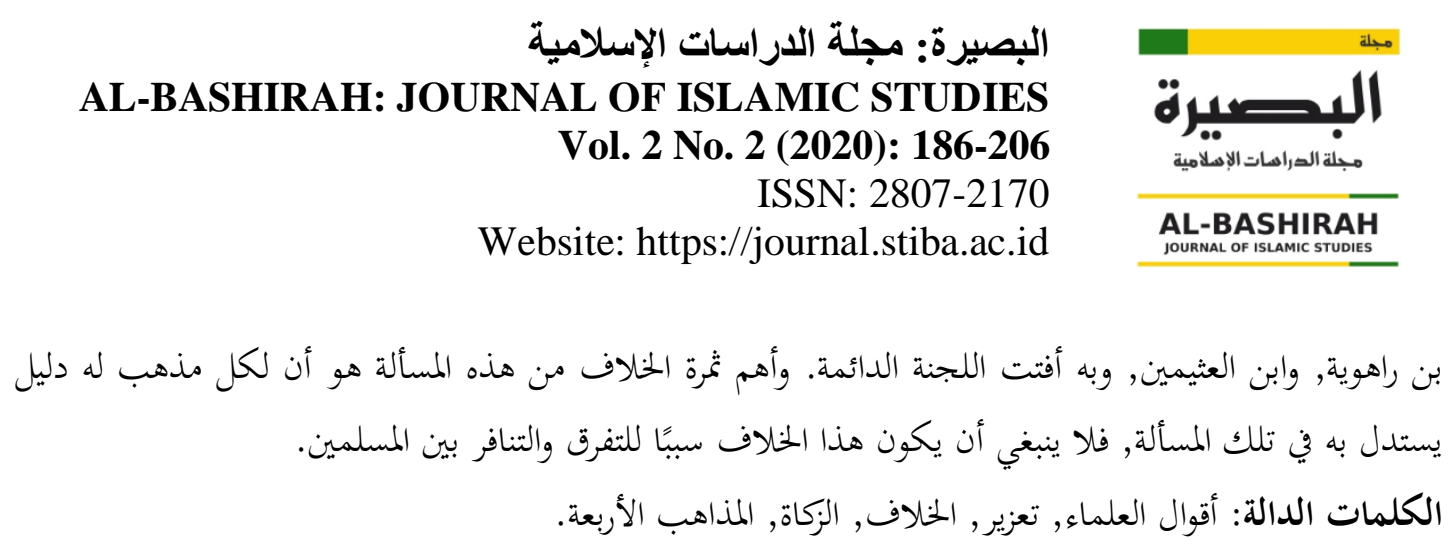

\title{
PUNISHMENT OF TA'ZIR FOR THOSE WHO ARE RELUCTANT TO PAY ZAKAT BY TAKING THEIR PROPERTY (FORCIBLY) ACCORDING TO THE PERSPECTIVE OF THE FOUR SCHOOLS OF JURISPRUDENCE
}

\author{
Mukran Usman \\ Sekolah Tinggi Ilmu Islam dan Bahasa Arab (STIBA) Makassar, Indonesia \\ Email:mukran@stiba.ac.id \\ Imran Bukhari \\ Sekolah Tinggi Ilmu Islam dan Bahasa Arab (STIBA) Makassar, Indonesia \\ Email: aboeabduh@gmail.com \\ Awal Rifai Wahab \\ Sekolah Tinggi Ilmu Islam dan Bahasa Arab (STIBA) Makassar, Indonesia \\ Email: awalrifai@stiba.ac.id

\section{Aris Firdaus} \\ Sekolah Tinggi Ilmu Islam dan Bahasa Arab (STIBA) Makassar, Indonesia \\ Email: arisfirdaus@gmail.com
}

\begin{abstract}
Zakat obligation is matter in religion that are logically already known. Refusing to pay zakat due to ignorance and greed is one of the great sins in afterlife law, and is among the most heinous crimes in worldly law. This research discusses the law of takzir against people who are reluctant to pay zakat by taking their property according to the four schools. This research aims to find out the opinions of the four schools of jurisprudence about the law of takzir against people who are reluctant to pay zakat by taking their property (forcibly), and to know the understanding of disputes of opinion about the takzir against people who are reluctant to pay zakat by taking their property according to four schools. The research methods used in research are inductivedeductive and comparative methods. The results showed that the four schools of jurisprudence agreed to impose takzir on people who are reluctant to pay zakat by taking their property forcibly according to the obligatory zakat rate on it without additional. While some scholars consider that takzir for people who are reluctant to pay zakat is to take their property forcibly according to the obligatory zakat rate on it
\end{abstract}

$$
\text { مكران عثمان, عمران بخارى,أول رفاعي وهاب , أريس فردوس, حكم تعزير مانع الزكاة... }
$$




\section{البصيرة: مجلة الاراسات الإسلامية \\ AL-BASHIRAH: JOURNAL OF ISLAMIC STUDIES \\ Vol. 2 No. 2 (2020): 186-206 \\ ISSN: $2807-2170$ \\ Website: https://journal.stiba.ac.id

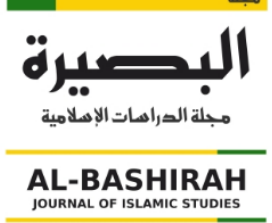

accompanied by additional punishment that takes half of its property. This is the opinion of the old Shafii (qaul qadim), one of the narration of Imam Ahmad, as well

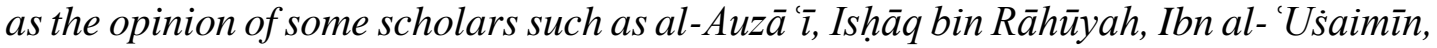
in addition to the opinion of the permanent of Fatwa Commission of the Kingdom of Saudi Arabia. As for the understanding of dissent in this matter is the knowledge that every school of jurisprudence has a proposition as a guideline to strengthen its opinion, so that the difference should not be the cause of division and hostility among the Muslims.

Keywords: opinions of scholars, takzir, dissent, zakat, four schools.

المقدمة

الزكاة فرض عين على كل من توفرت فيه شروط وجوبها، وقد ثبتت فرضيتها بالكتاب والسنة والإجماع. 1 أما الكتاب فقد تضافرت آيته في إيجاب الزكاة والعناية بها، حتى أهما قُرنت بالصلاة في اثنتين

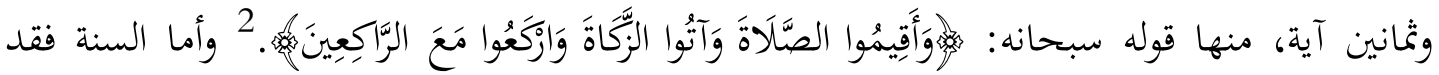
جاءت بتأكيد وجوب الزكاة، فعن ابن عباس رضي الله عنهما: أن النبي صلى الله عليه وسلم لما بعث معاذ بن جبل رضي الله عنه إلى اليمن قال: 》إنك تأتي قومًا أهل كتاب، فادعهم إلى شهادة أن لا إله إلا الله وأني رسول الله، فإن هم أطاعوا لذلك فأعلمهم أن الله عز وجل افترض عليهم خمس صلوات في كل يوم وليلة، فإن هم أطاعوا لذلك، فأعلمهم أن الله تعالى افترض عليهم صدقة من أموالهم، تؤخذ من أغنيائهم وترد إلى فقرائهم، فإن هم أطاعوا لذلك فإياك وكرائم أموالهم، واتق دعوة المظلوم، فإنه ليس بينها وبين الله حجابه.3 وقد اتفق الإجماع على فرضية الزكاة لم يخالف أحد من لدن رسول الله صلى الله عليه وسلم إلى يومنا هذا. 4 ولما جاءت الشريعة الإسلاميّة تكفّلت بالمحافظة على الضروريّات الخمس وهي: حفظ الدين، وحفظ النفس، وحفظ النسل، وحفظ المال، وحفظ العقل، كما أفها منعت وجرّمت وحرَّمت كلَّ اعتداء يحول دون تحقيق هذه الضروريات أو المساس بها، وقد فرضت الشريعة الإسلاميّة السمحة كذلك عقوبات محدَّدة ورادعة بحقِّ كل من يعتدي على هذه الضروريات أيّاّكان شخصه أو موقعه في الدولة. 1 أبو مالك كمال بن السيد سالم ، صحيح فقه السنة وأدلته وتوضيح مذاهب الأئمة، ج 2 (القاهرة: المكتبة التوفيقية، 2003 م) ص

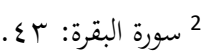

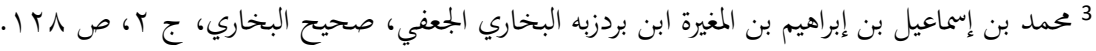

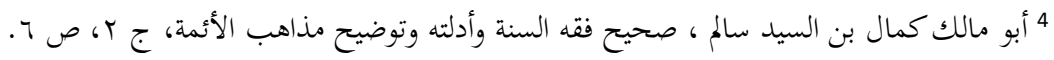


إنّ للزكاة تعريفات عدة في اللغة والاصطلاح الزكاة فريضة من فرائض الدين، وهي الركن الثالث من أركان الإسالام الخمسة بعد الشهدتين والصلاة. فالزكاة لغة هي النماء والزيادة والبركة والمدح والثناء والصلاح وصفوة الشيء، والطهارة حسية أو معنوية، وبمعنى: زكاة المال. 5 وقال محمد بن مكرم بن

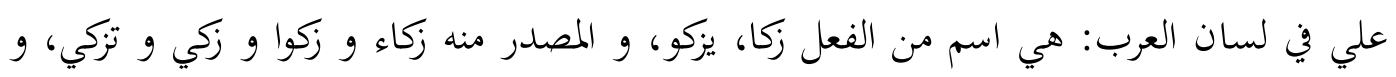
زكاه الله، و زكا نفسه تزكية: مدحها. 6

$$
\text { أما الزكاة شرعًا على المذاهب الأربعة: - ماهب }
$$

أ. فقد عرفها الحنفية بقولهم: "الزكاة هي تمليك المال من فقير مسلم غير هاشمي ولا مولاه بشرط

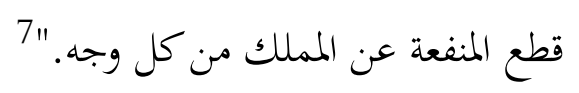

ب. وعرفها المالكية بأنها: "الجزء المخصوص المخرج من المال المخصوص إذا بلغ نصابا المدفوع

$$
\text { لمستحقه إن تم الملك وحول غير المعدن." }
$$

ج· وقال الشافعية في تعريفها: "اسم لاخذ شئ غخصوص من مال مخصوص على أوصاف خصوصة لطائفة مخصوصة."

د. وقال الحنابلة: "حق واجب في مال خاص، لطائفة خصوصة، في وقت مخصوص."10 2. تعريف التعزير

$$
\begin{aligned}
& 5 \text { محمد بن أبي بكر بن عبد القادر الحنفي الرازي، غختار الصحاح، ص } 136 .
\end{aligned}
$$

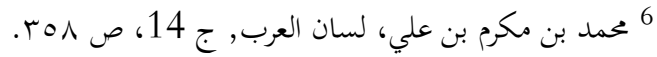

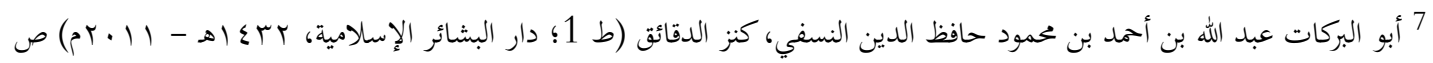

$$
\begin{aligned}
& 8 \text { محمد بن أحمد بن عرفة الدسوقي المالكي، حاشية الدسوقي على الشرح الكبير، ج } 1 \text { (دار الفكر) ص } 4303 \text { ص } 430 .
\end{aligned}
$$

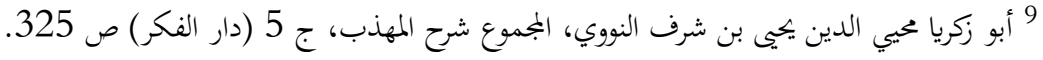

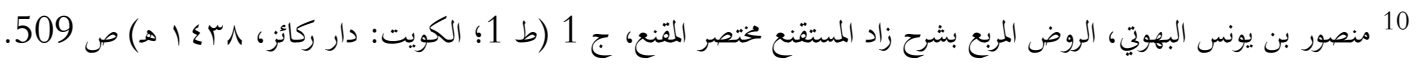


التعزير في اللغة: التأديب، عزر أي: أدّب، وأصله من العزر بمعنى الردع والرد، و تأتي أيضاً بمعنى أعان

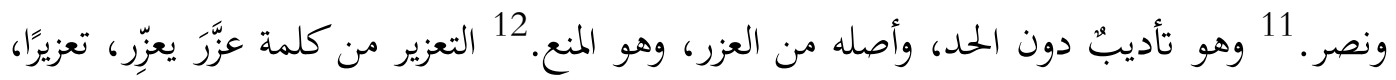

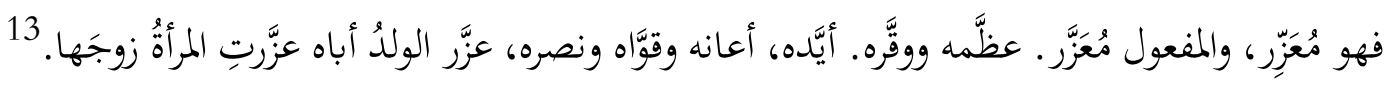

أما في الاصطلاح فقد عرفه الفقهاء بتعريفات متعددة متقاربة، ويمكن أن نعرفه بأنه: العقوبة المشروعية غير المقدّرة شرعاً، والتي يوقعها القاضي على المجرم لمعاقبته بما يكافئ جريمته، ويقمع عدوانه، ويحقّق الزجر والإصلاح، ويكون في كل جريمة لا حدّ فيها ولا كفارة، سواء أكانت الجناية اعتداء على لئى حق الله تعالى، كالأكل في هار رمضان بغير عذر، وترك الصالة، أم كانت اعتداء على حقوق العباد

كالربا، وطرح النجاسة، وأنواع الأذى في طريق الناس، والسب والشتم وغير ذلك من الجرائم. 14

\section{الدراسات السابقة المتعلقة بهذا البحث ما يلي:}

1. أحكام التعزير بالمال في الشريعة الإسلامية مقارنة بالقانون اليمني لمحمد أحمد يهيى الخاشب، رسالة ماجستير، من جامعة الإيمان، اليمن، (2010م). والرسالة عبارة عن بابين، ذكر في الباب الأول:

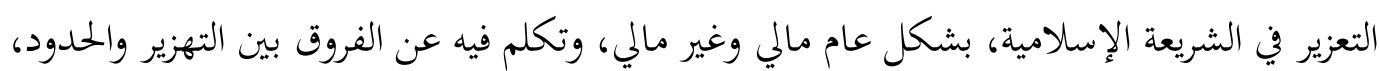
كما ذكر فيه أقسام التعزير إجمالا. وفي الباب الثاني تحدث عن التعزير بالمال في الشريعة والقانون، وقد تطرق إلى التعزير بالمال في الشريعة والقانون اليمني كمقارنة في مبحث ومطلب واحد فقط، بعد أن قسم المال إلى متقوم وغير متقوم، ثم ذكر بعد ذلك مسائل وصور على التعزير بالمال. ولكن هذا البحث لا يذكر عن التعزير لمانع الزكاة.

2. أحكام الغرامة المالية في الفقه الإسلامي عصام أنس الزفتاوي، كتاب من مطبوعات المعهد العالمي للفكر الإسلامي، القاهرة، (1997م)، تناول فيه آراء الكتاب المعاصرين في الغرامة المالية، وذكر أدلة المجيزين والمانعين، لكنه:-اقتصر على بعض أدلة القائلين بالعقوبات المالية ولم يذكرها كاملة وأغفل أهمها. -لم يكن تحليل الأدلة دقيق، مما يشعر القارئ بنقص كبير في البحث. لم يتطرق لأنواع العقوبات

$$
11 \text { محمد بن مكرم بن على، لسان العرب، ج 4، ص } 12 .
$$

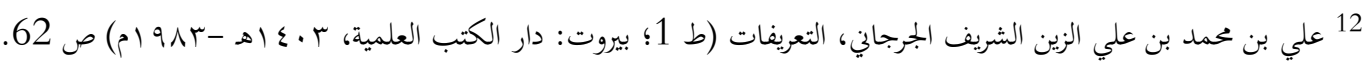

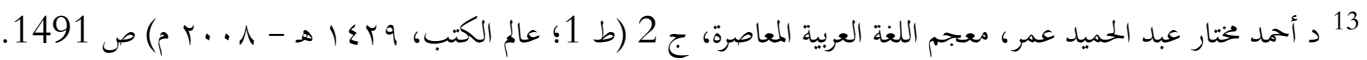

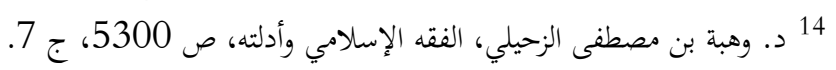




\section{البصيرة: مجلة الاراسات الإسلامية \\ AL-BASHIRAH: JOURNAL OF ISLAMIC STUDIES \\ Vol. 2 No. 2 (2020): 186-206 \\ ISSN: $2807-2170$ \\ Website: https://journal.stiba.ac.id

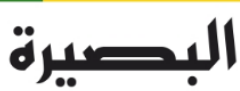 \\ مجلة الصراهات الإهلامية \\ AL-BASHIRAH}

المالية ولا صورها المعاصرة.كان الكتاب خالي من المقارنة بالقانون،و كذلك تطبيقات العقوبات على

القضاء.

أقوال المذاهب الأربعة عن تعزير مانع الزكاة بأخذ المال

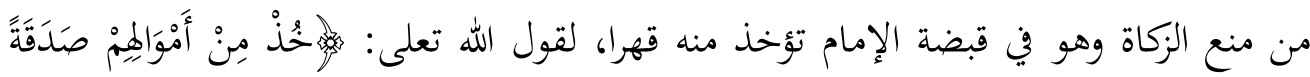

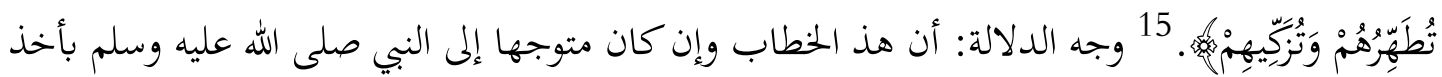
الزكاة إلا أنه يقوم مقام النبي صلى الله عليه وسلم فيه الخمفاء والأمراء من بعده. 16

عن أبي معبد، عن ابن عباس رضي الله عنهما: أن النبي صلى الله عليه وسلم بعث معاذا رضي

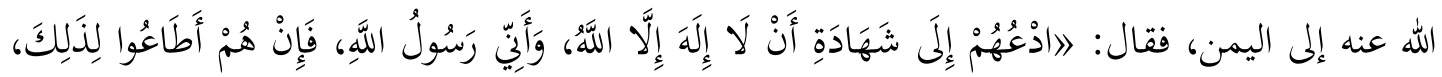

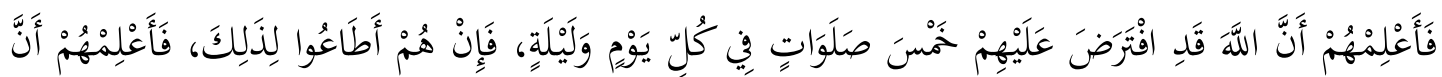

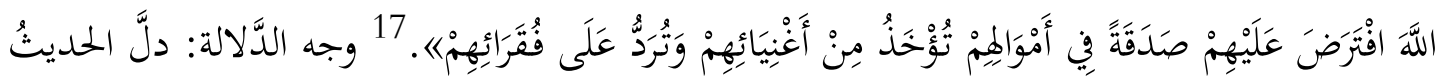

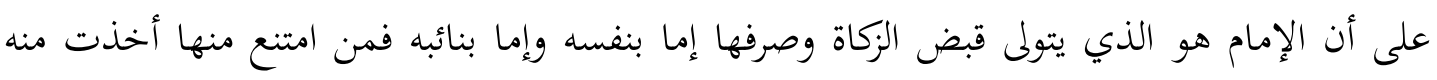

نقل الإجماع على أخذ الزكاة من مانعها قهرا. قال ابن بطال: أجمع العلماء على أن مانع الزكاة تؤخذ من ماله قهرًا. 19 وقال أبو عمر لا خلاف بين العلماء أن للإمام المطالبة بالزكاة وأن من أقر بوجوبها عليه أو قامت عليه بها بينة كان للإمام أخذها منه. 20 بعد ما تكلم الباحث عن حكم مانع الزكاة مجمالا، وبعد قليل سيذكر الباحث عن أقوال المذاهب الأربعة عن حكم تعزير مانع الزكاة بأخذ المال مع أدلتهم وما هو القول المعترب عند مذهبهم الذي ذهب إليه من يتمذهب مبذهبهم. 15 16 أبو عمر يوسف بن عبد الله بن محمد بن عبد البر بن عاصم النمري القرطبي، الاستذكار، ج 2 (ط 2؛ بيروت، دار الكتب العلمية) ص 406.

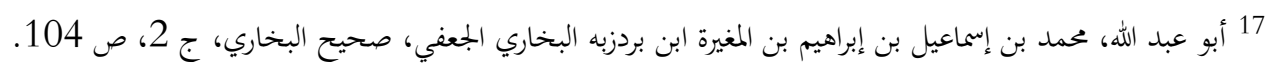

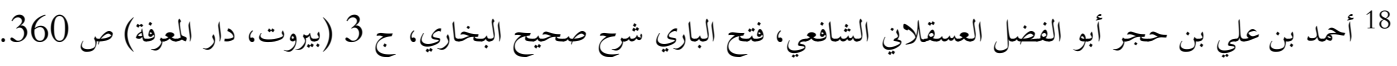

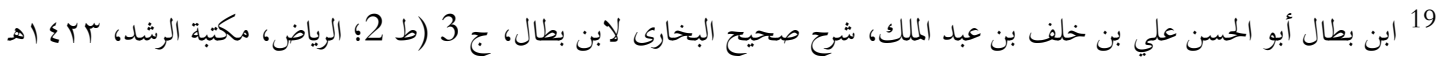

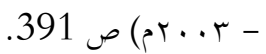
20 أبو عمر يوسف بن عبد الله بن محمد بن عبد البر بن عاصم النمري القرطبي، الاستذكار، ج 3، ص 217. 
البصيرة: مجلة الاراسات الإسلامية

AL-BASHIRAH: JOURNAL OF ISLAMIC STUDIES

Vol. 2 No. 2 (2020): 186-206

ISSN: $2807-2170$

Website: https://journal.stiba.ac.id

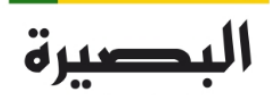

مجلة الصراهات الإصلامية

AL-BASHIRAH

JOURNAL OF ISLAMIC STUDIES

أ. تعزير مانع الزكاة بأخذ المال عندالحنفية مقارنة بين المذاهب الأربعة عن تعزير مانع الزكاة بأخذ المال

إذا امتنع من أداء الزكاة ولم يجحد وجوبها أخذت وعزر ولا يأخذ زيادة على الواجب. وقال

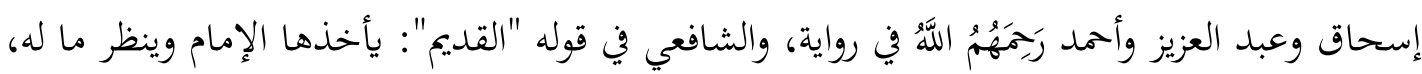
وهي رواية عن إسحاق رَحمَهُ اللَّهُ يؤخذ معها مثلها.

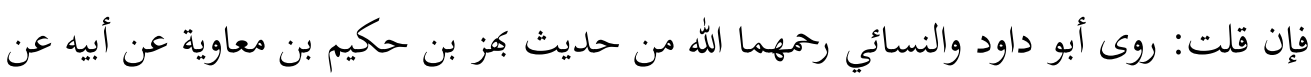

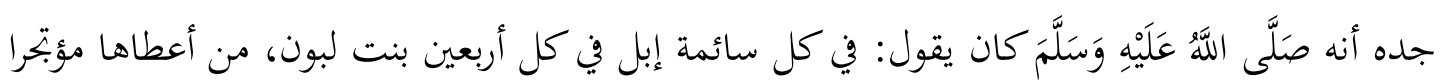

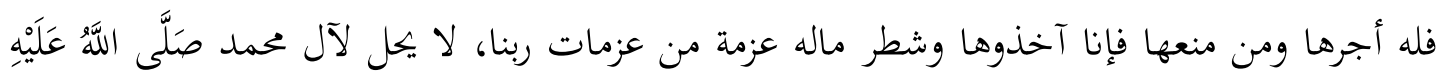

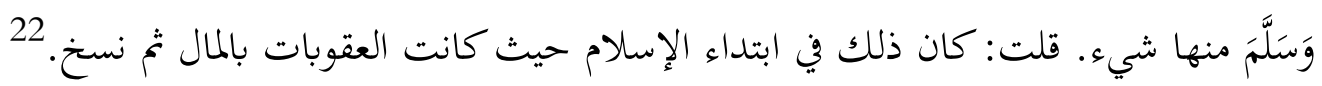

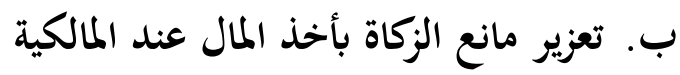

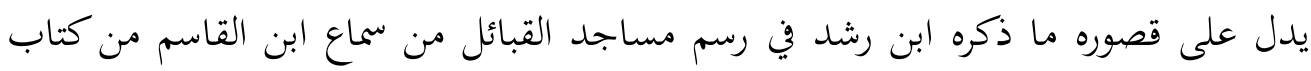

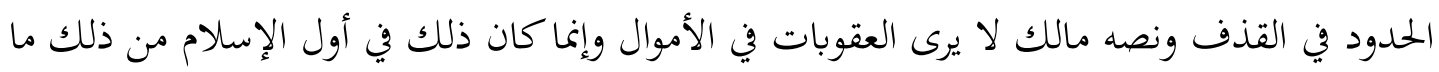

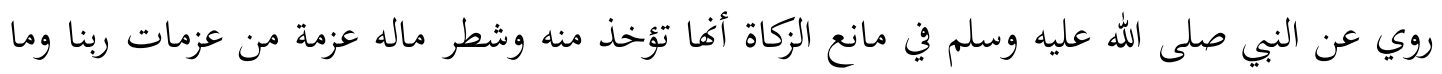

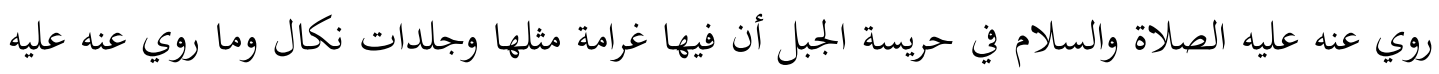

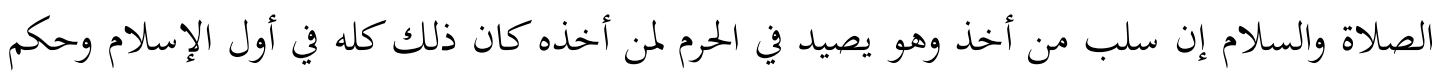

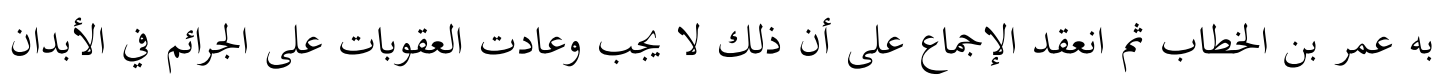

قال مالك يجزئ قال أشهب طوعا أو كرها لأن تصرفات الخوارج نافذة، وإلا فسدت أنكحة

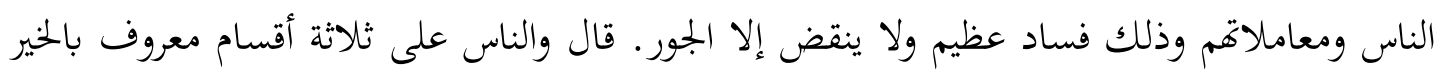

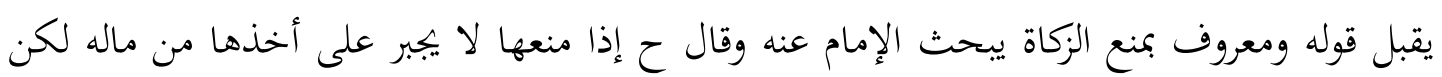

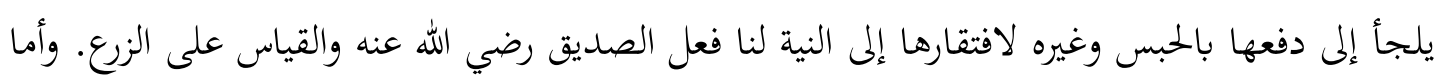

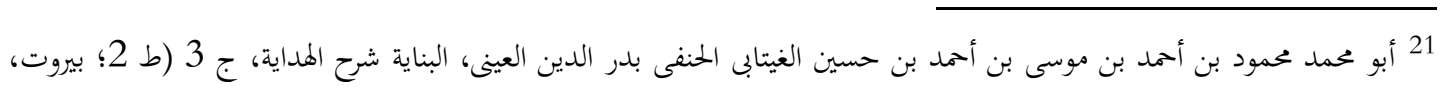

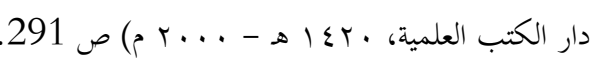

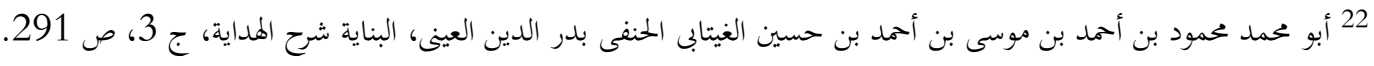

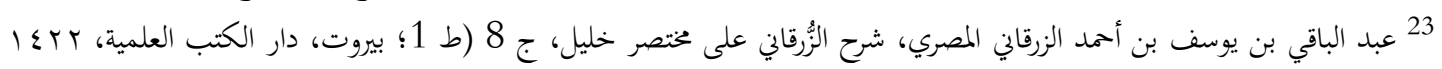

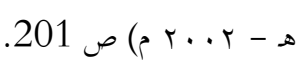


النية فإنها إنما اشترطت لما فيها من شائبة العبادة التي هي تبع لسد الخلة فإذا منع المتبوع لا يسقط لتعذر المار التابع أو نقول نية الإمام تقوم مقام نيته ولا يؤخذ من أموالمم أكثر من الزكاة. 24

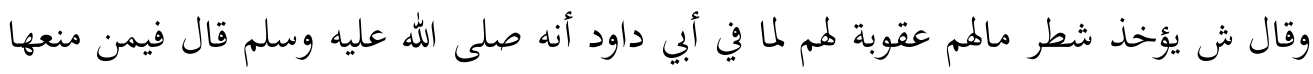

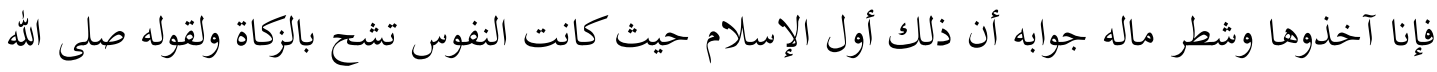

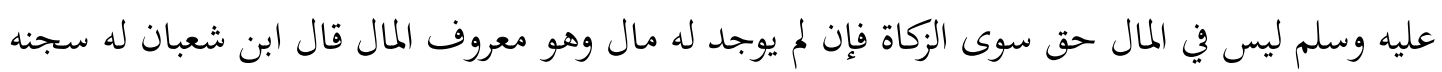

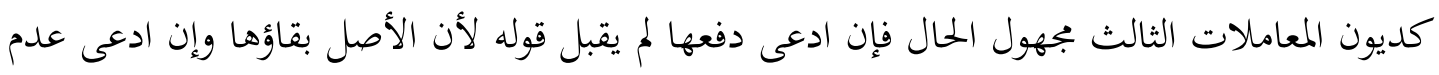

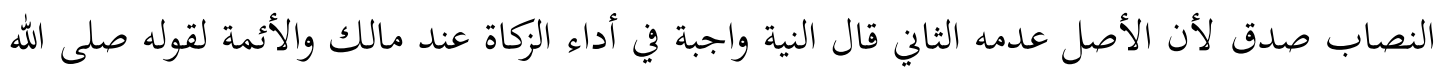
عليه وسلم. 25

\section{تعزير مانع الزكاة بأخذ المال عند الشافعية}

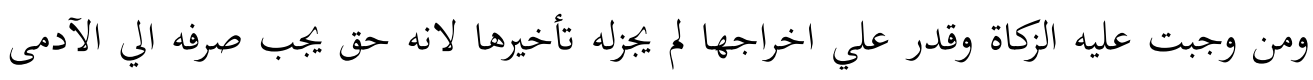

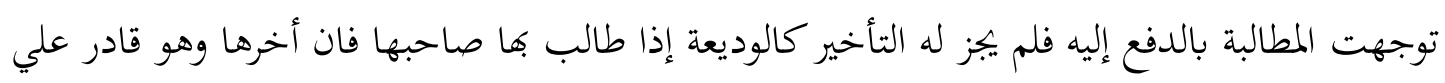

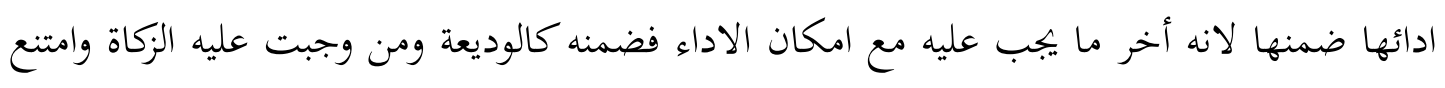

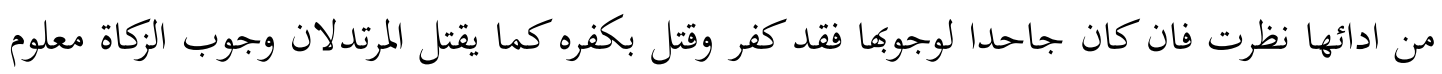

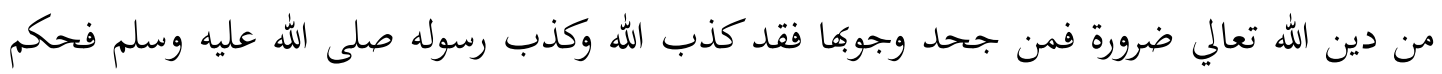
بكفره وان منعها بخلابها أخذت منه وعزر.

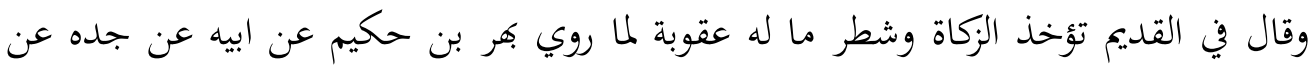

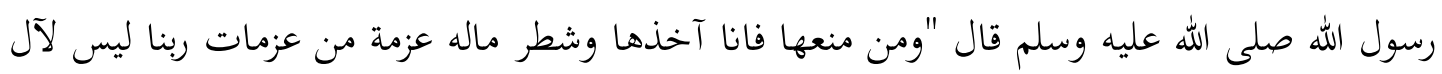

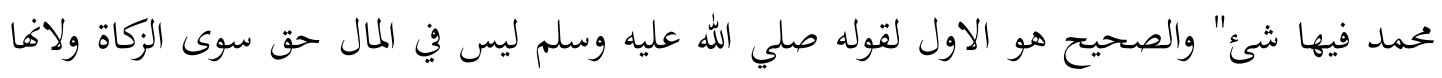

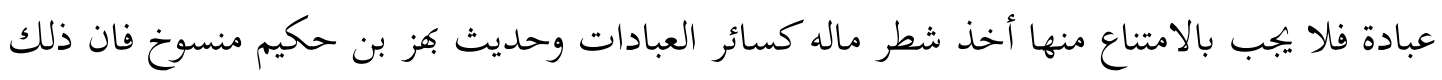

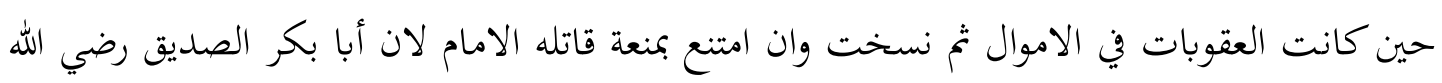
عنه قاتل مانعي الزكاة.

\footnotetext{
أبو أبعاس شهاب الدين أمد بن إدريس بن عبد الرمن المالكي الشهير بالقرافي، الذخيرة، ج3 (ط 135 بيروت، دار الغرب الإسلامي،

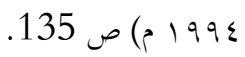

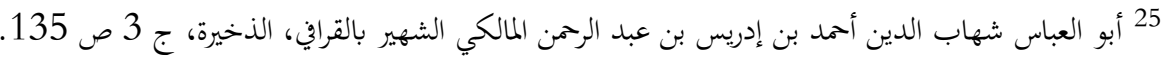

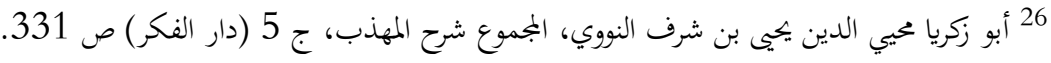

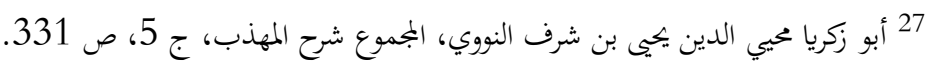


البصيرة: مجلة الاراسات الإسلامية

AL-BASHIRAH: JOURNAL OF ISLAMIC STUDIES

Vol. 2 No. 2 (2020): 186-206

ISSN: $2807-2170$

Website: https://journal.stiba.ac.id

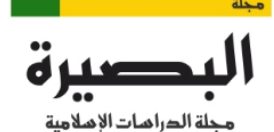

مجلة الصراهات الإصلامية

AL-BASHIRAH

إذا ناب في إخراج الزكاة عن المالك غيره، فله صور . منها: نيابة الولي عن الصبي والمجنون، فيجب

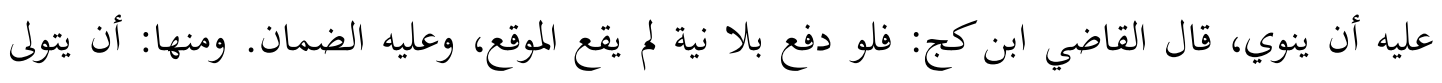

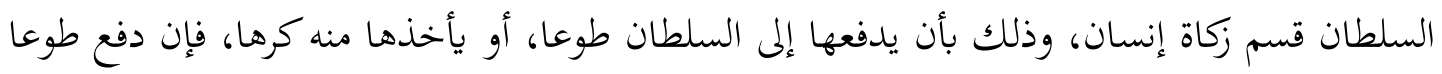

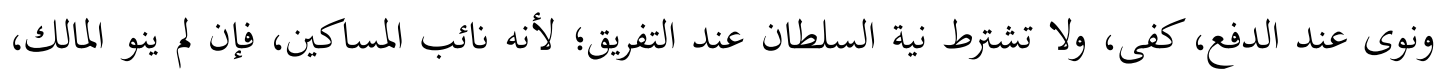

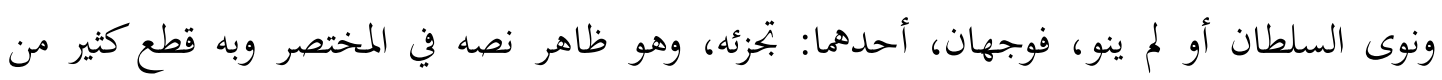

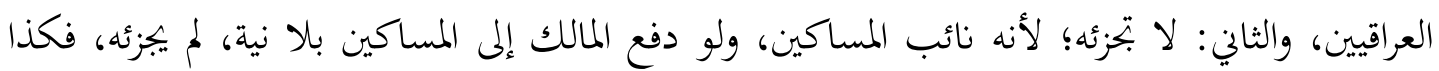

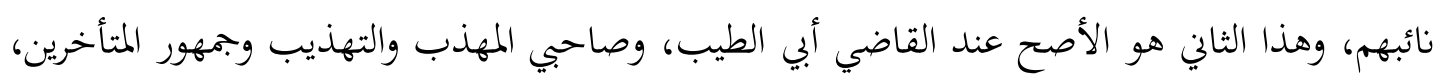

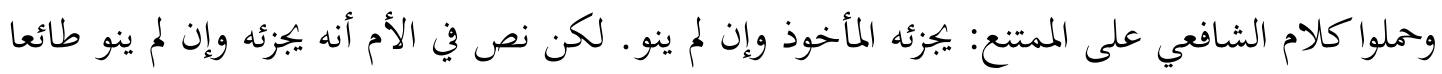

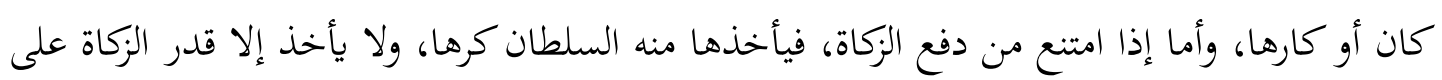

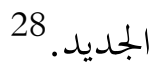

وقال في القديم: يأخذ مع الزكاة شطر ماله. قلت: المشهور هو الجديد، والحديث الوارد في سنن

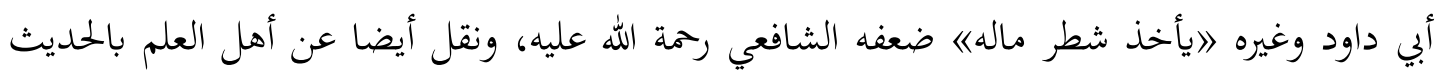

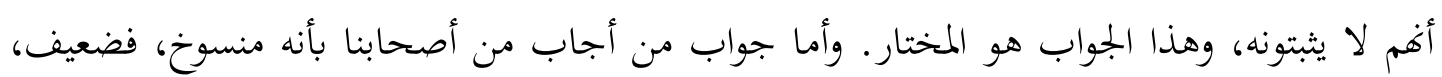
فإن النسخ يحتاج إلى دليل، ولا قدرة لهم عليه هنا، والله أعلم. 29

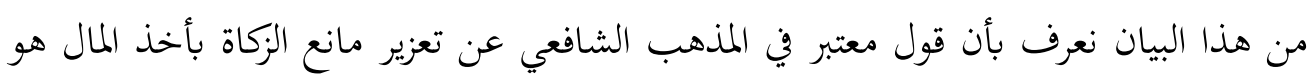

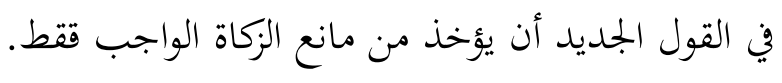

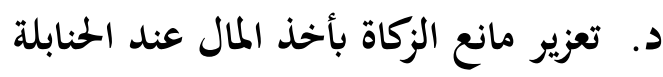

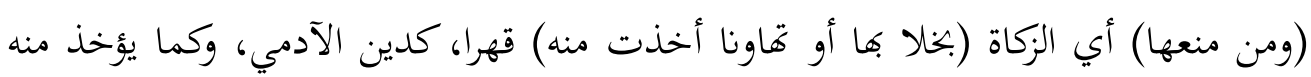

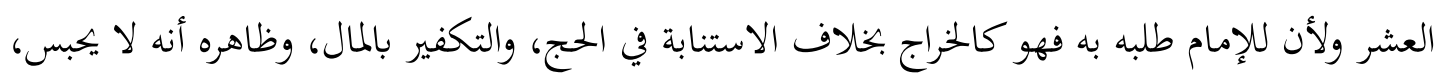
حتى يؤدي لعدم النية في العبادة من الممتنع (وعزره إمام عدل فيها) أي في الزكاة يضعها مواضعها.

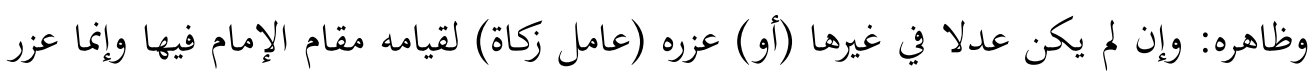

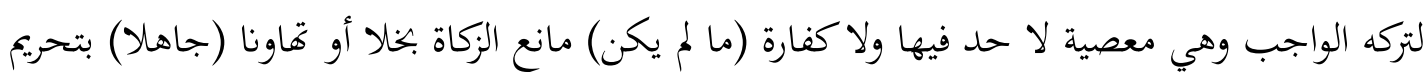
28 أبو زكريا ميي الدين يجيى بن شرف النووي، روضة الطالبين وعمدة المفتين، ج 3 (ط 3؛ بيروت، المكتب الإسلامي، باءع اهـ / ( 29)

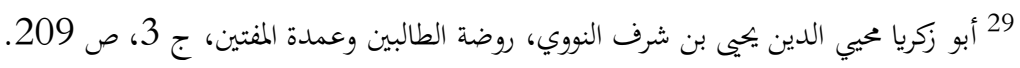
30 منصور بن يونس بن صلاح الدين ابن حسن بن إدريس البهوتى الحنبلى، كشاف القناع عن من متن الإقناع، جع 2 (دار الكتب العلمية) 
ذلك فلا يعزر لأنه معذور.(وإن فعله) أي منع الزكاة (لكون الإمام غير عدل فيها لا يضعها مواضعها

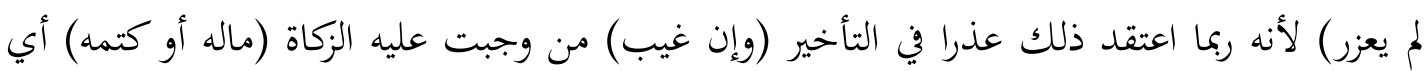

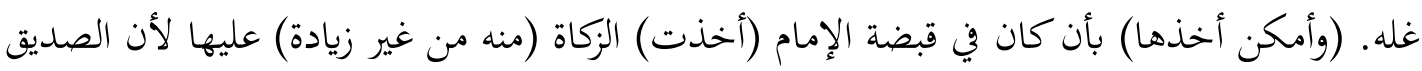

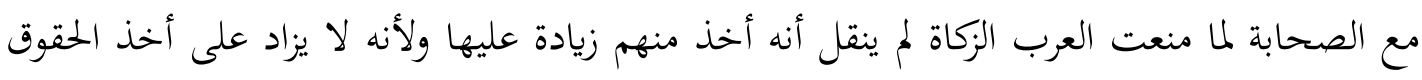
من الظالم كسائر الحقوق.

فصل: وإن منعها معتقدا وجوبها، وقدر الإمام على أخذها منه، أخذها وعزره، ولم يأخذ زيادة

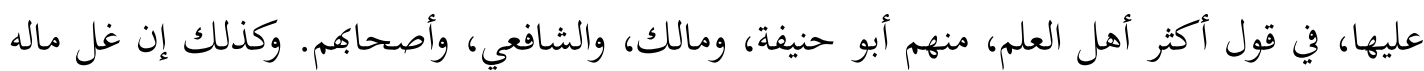

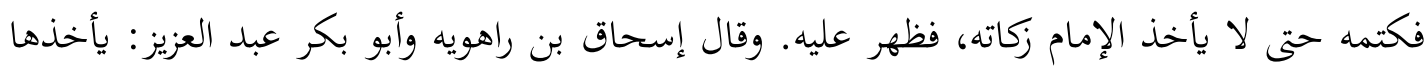

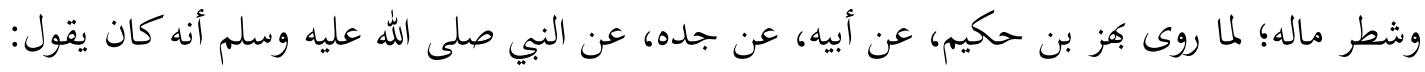

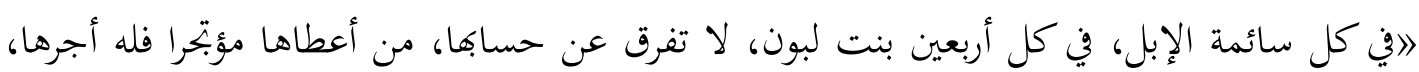

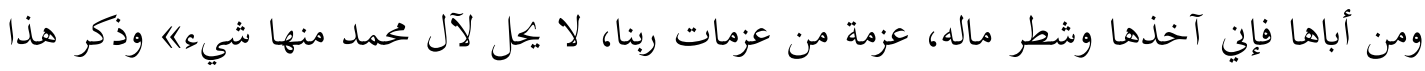

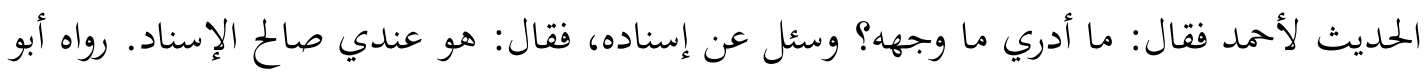
داود، والنسائي، في "سننهما". 32 ووجه الأول، قول النبي صلى الله عليه وسلم: 》ليس في المال حق سوى الزكاة)، ولأن منع الزكاة كان في زمن أبي بكر رضي الله عنه بموت رسول الله صلى الله عليه وسلم مع توفر الصحابة رضي الله الها

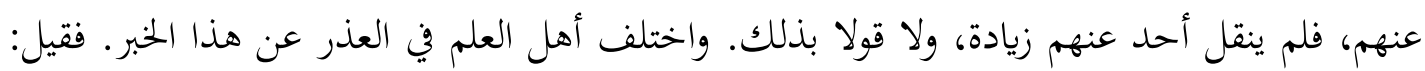

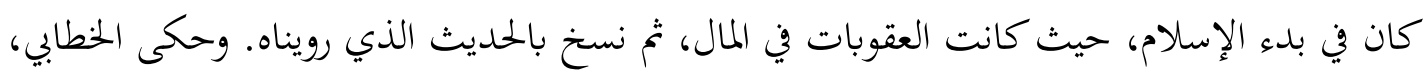

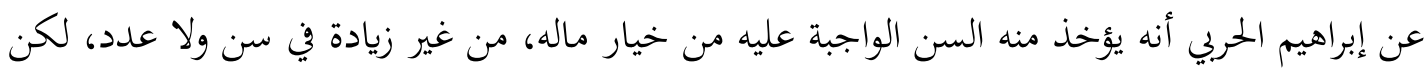

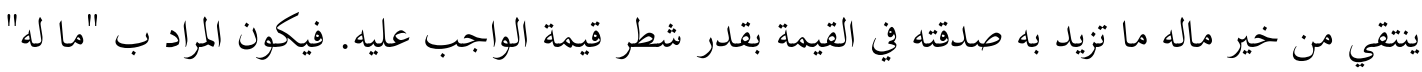

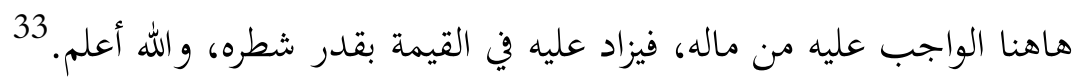

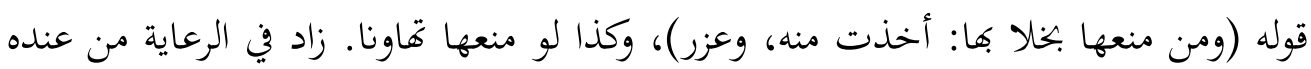

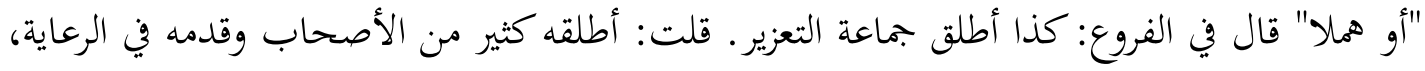

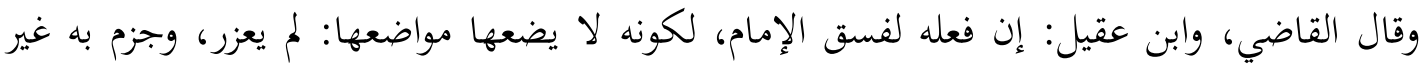

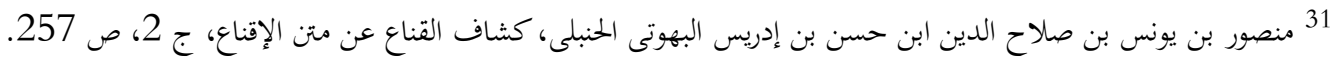

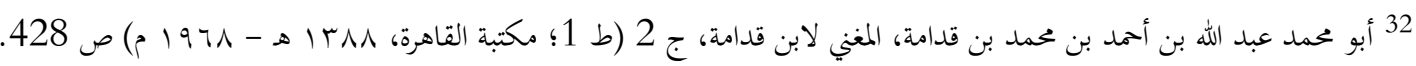

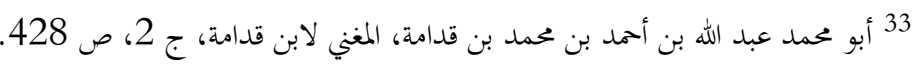


واحد من الأصحاب، منهم صاحب الرعاية، والفائق. قلت: وهذا الصواب. بل لو قيل: بوجوب كتمانه

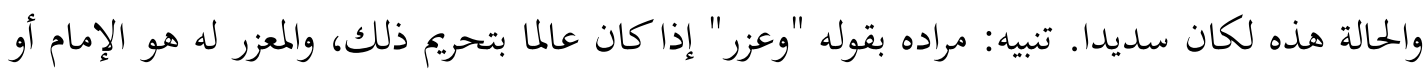

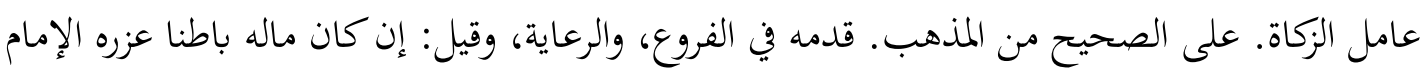
34 أو المختس

قوله (فإن غيب ماله، أو كتمه، أو قاتل دونا، وأمكن أخذها، أخذت منه من غير زيادة) ، أحسا،

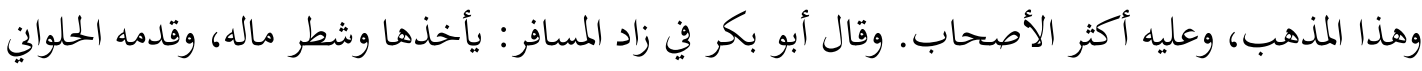

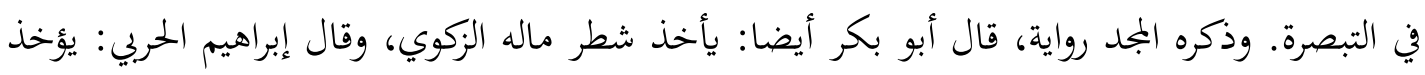

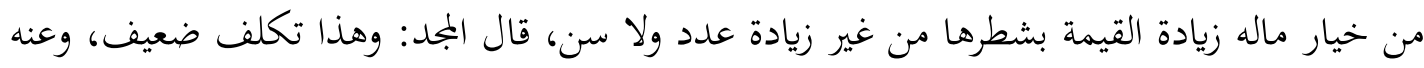

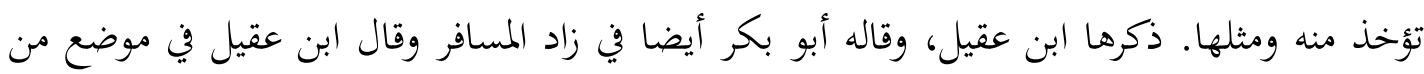

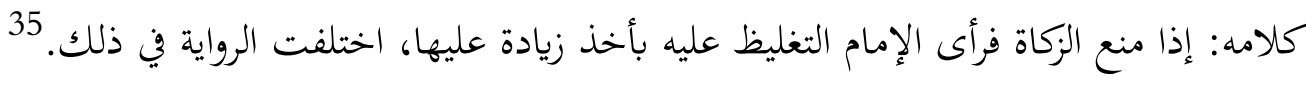

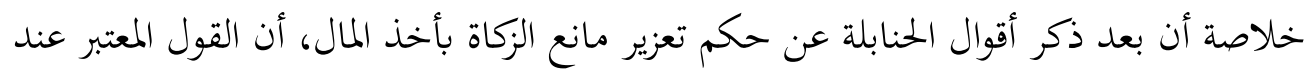

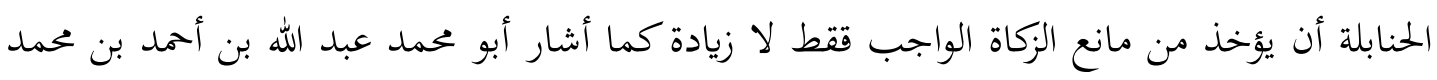

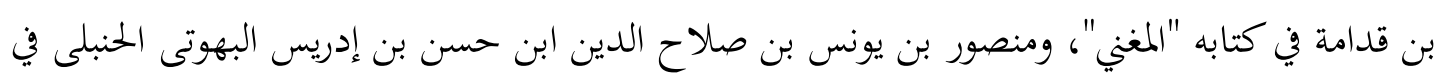
كتابه "كشاف القناع عن متن الإقناع". هـ المقارنة بين المذاهب الأربعة عن تعزير مانع الزكاة بأخذ المال المال

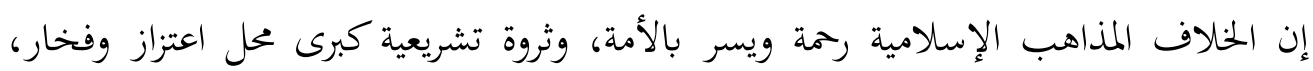

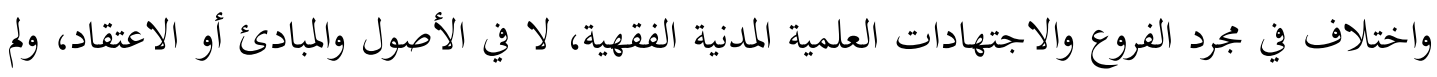

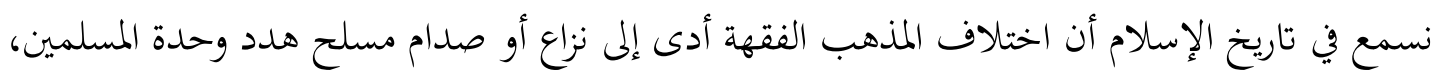

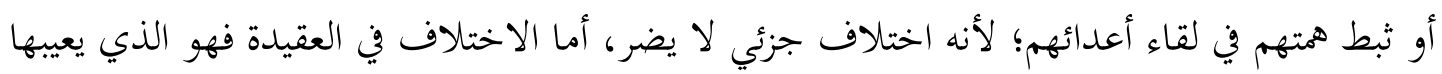

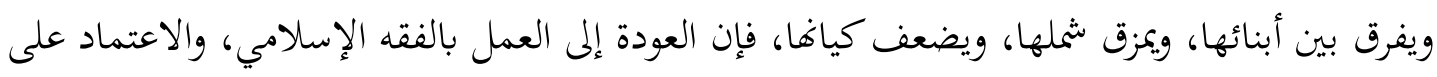
تقنين موحد مستمد منه سبيل لتدعيم وحدة الأمة الإسلامية ونبذ خلافتها.

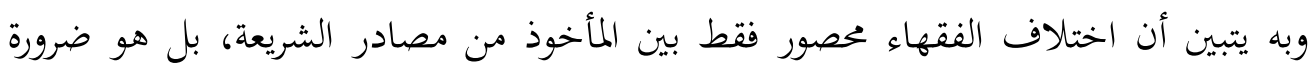

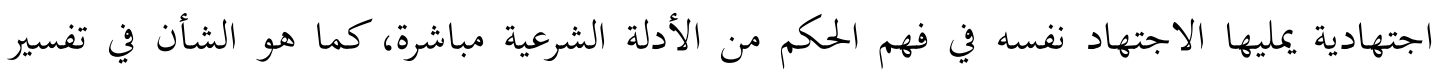

دار علاء الدين أبو الحسن علي بن سليمان المرداوي الدمشقي الصالحي الحنبلي، الإنصاف في معرفة الراجح من الملاف، ج 3 (ط 2؛

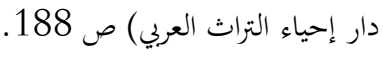
35 علاء الدين أبو الحسن علي بن سليمان المرداوي الدمشقي الصالحي الحنبلي، الإنصاف في معرفة الراجح من الملاف، ج 3، ص 188. 
البصيرة: مجلة الاراسات الإسلامية

AL-BASHIRAH: JOURNAL OF ISLAMIC STUDIES

Vol. 2 No. 2 (2020): 186-206

ISSN: $2807-2170$

Website: https://journal.stiba.ac.id

البحصيرة

مجلة الدراهات الإصلامية

AL-BASHIRAH

نصوص القوانين، واختلاف الشراح فيما بينهم، وذلك إما بسبب طبيعة اللغة العربية المجملة أو المتملة

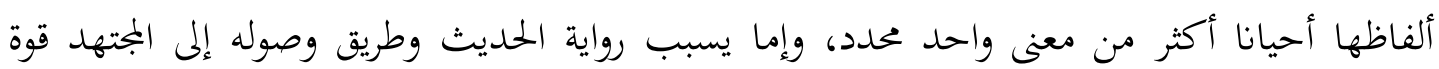

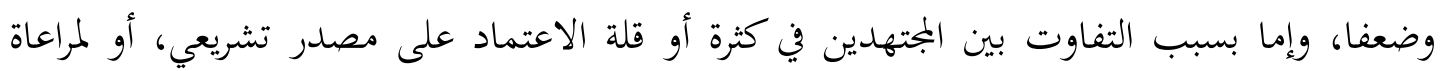

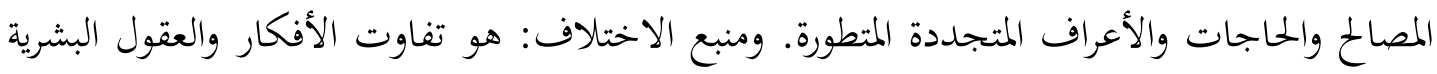
في فهم النصوص واستنباط الأحكام، و إدراك أسرار التشريع وعلل الأحكام الشرعية.

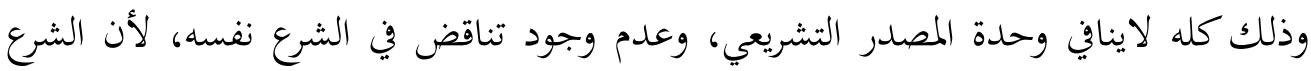

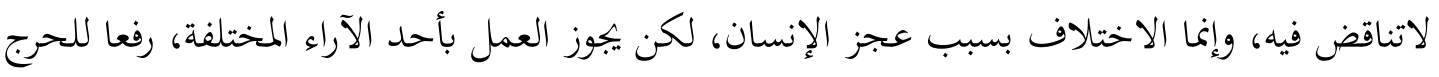

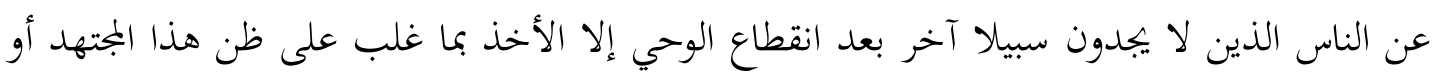

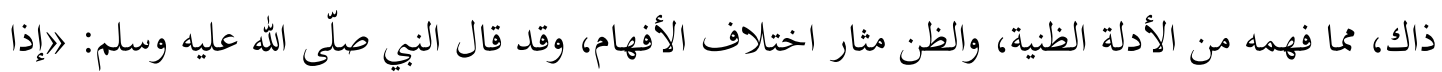

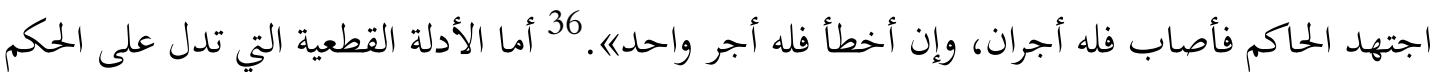

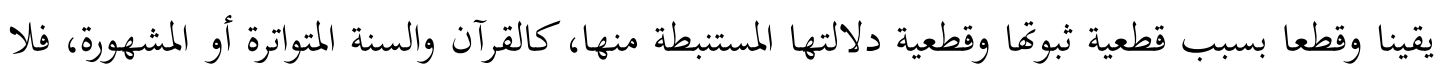
مجال أصلاً لاختلاف الفقهاء في الأحكام المستفادة منها.

وأهم أسباب اختلاف الفقهاء في استنباط الأحكام الشرعية من الأدلة الظنية هو ما يأتي:

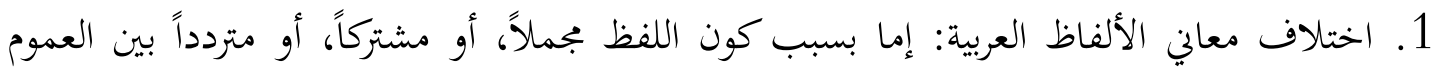

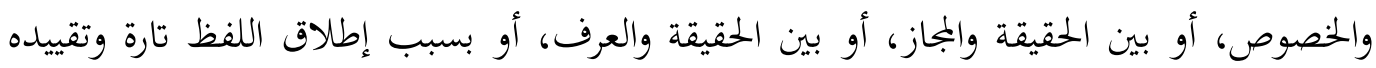

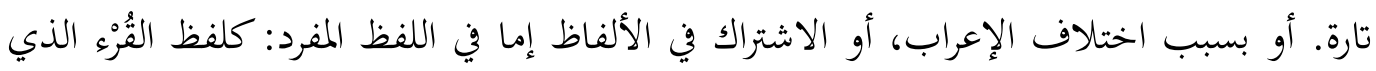

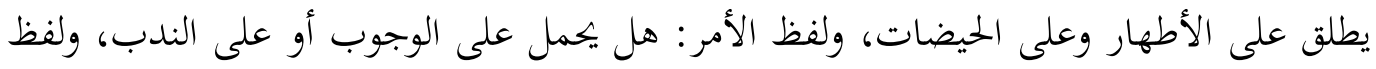

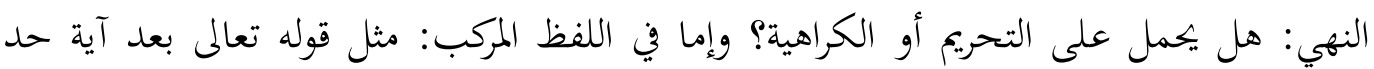

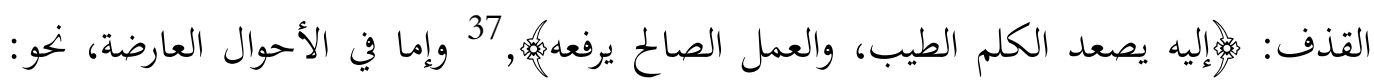
38 . 38 .

2. اختلاف الرواية: وله أسباب ثمانية، كأن يصل الحديث إلى أحدهم ولايصل إلى غيره، أو يصل من

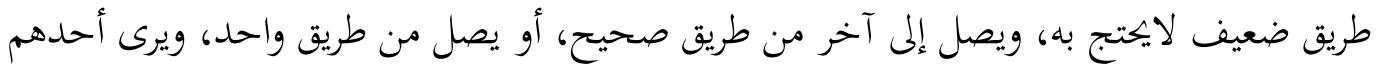

36 كمد بن إسماعيل أبو عبد الله البخاري الجعفي، الجامع المسند الصحيح المختصر من أمور رسول الله صلى الله عليه وسلم وسنهن وأيامه،

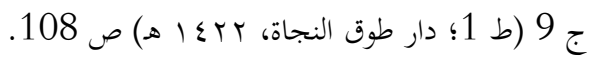
35 : 37 سورة فاط 35 - 2 38 


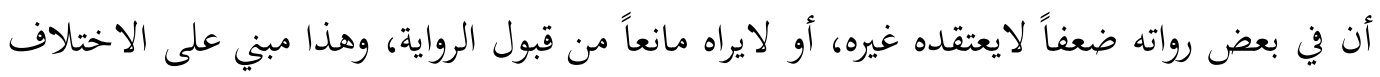

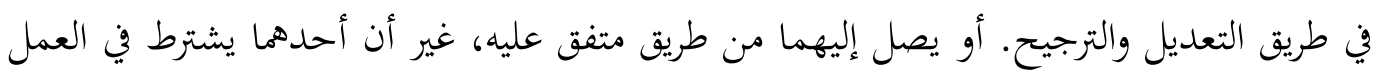
به شروطاً لا يشترطها الآخر، كالحديث المرسل آلمرسل.

3. اختلاف المصادر: وهناك أدلة اختلفوا في مدى الاعتماد عليها، كالاستحسان والمصالح لمانح المرسلة وقول الصحابي والاستصحاب، والذرائع ونوها من دعوى البراءة أو الإباحة وعدمها.

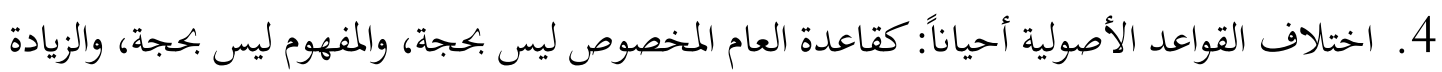
على النص القرآي نسخ أم لا، ونخو ذلك.

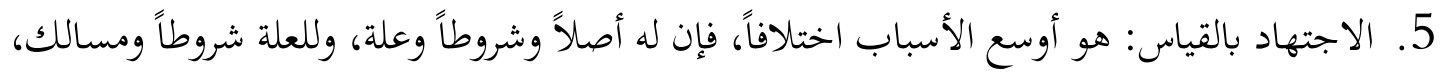

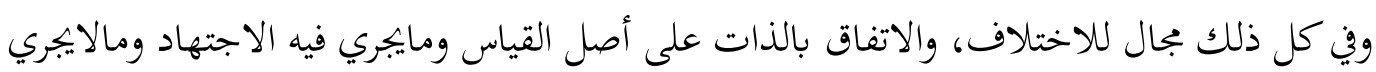

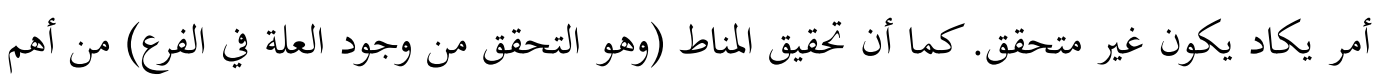
أسباب اختلاف الفقهاء. 6. التعارض والترجيح بين الأدلة: وهو باب واسع اختلفت فيه الأنظار وكثر فيه الجدل. وهويتناول

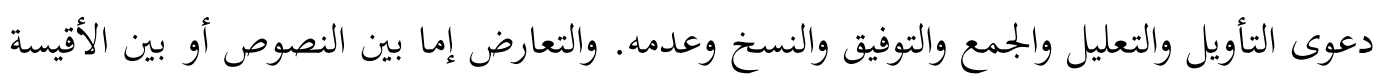

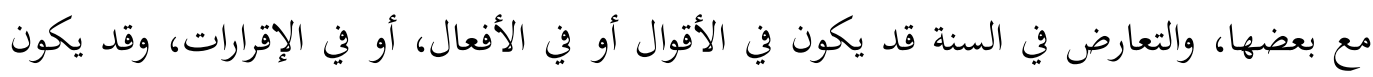

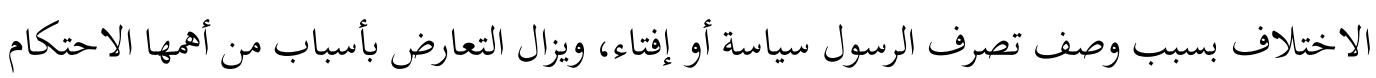
إلى مقاصد الشريعة، وإن اختلفت النظرة إلى ترتيب المقاصد.

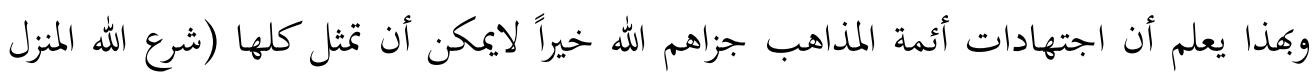

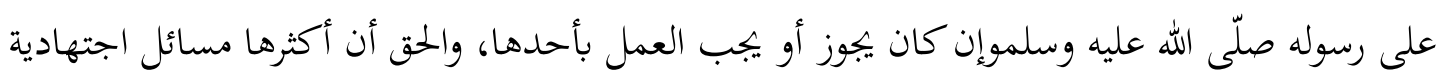

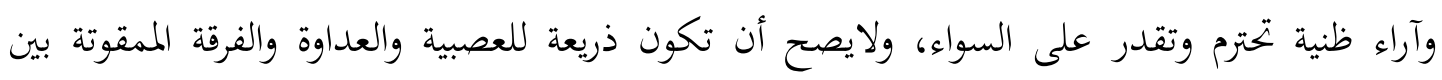

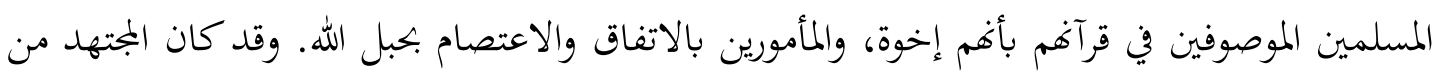

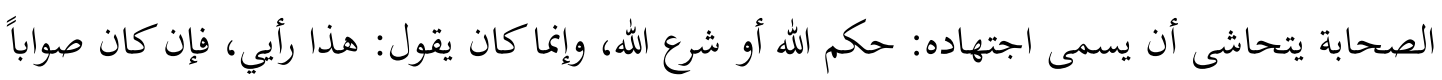

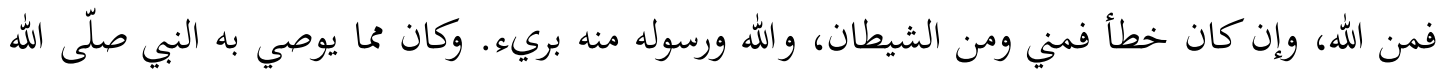




\section{البصيرة: مجلة الاراسات الإسلامية \\ AL-BASHIRAH: JOURNAL OF ISLAMIC STUDIES \\ Vol. 2 No. 2 (2020): 186-206 \\ ISSN: $2807-2170$ \\ Website: https://journal.stiba.ac.id

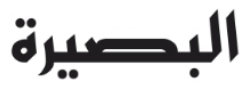 \\ مجلة الصراهات الإهلامية \\ AL-BASHIRAH}

عليه وسلم أمير الجيش أو السرية قوله: (وإذا حاصرت حصناً فأرادوك أن تنزهم على حكم الله، فلاتنزمم على حكم الله، ولكن أنزهم على حكمك، فإنك لاتدري، أتصيب حكم الله فيهم أم لا). 40 فقد تقدمت أقوال المذاهب الأربعة وأدلتهم عن تعزير مانع الزكاة بأخذ المال من بعد، وعرفنا بأن

اختلف أهل العلم في عقوبة مانع الزكاة بأخذ زيادة على الواجب منه أو لا . وذلك على القولين: 1. القول الأول: يؤخذ من مانع الزكاة الواجب فقط، وهذ بالتفاق المذاهب الفقهية الأربعة؛ الحنفية

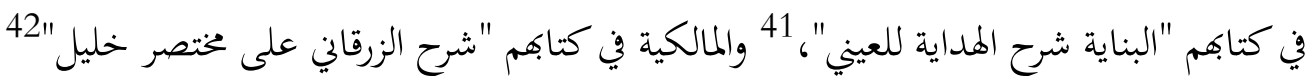
و " الذخيرة للقرافي"، 43 والشافعية في كتاهم "المجموع شرح المهذب"، 44 وروضة الطالبين"، 45 والحنابلة في كتاهم "المغني لابن قدامة"46 و و "كشاف القناع عن متن الإقناع". 47 وأدلة على ولى

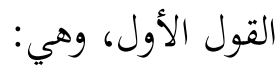

أ) أن الزكاة منعت في زمن أبي بكر رضي الله عنه بعد وفاة النبي صلى الله عليه وسلم، ولم ينقل 48

أن أحدا أخذ زيادة على الواجب، أو قال بذلك مع توفر الصحابة رضي الله عنهم.

ب) أن الزكاة عبادة، فلا يجب بالامتناع منها أخذ شطر ماله، كسائر العبادات. 49 ج) أنه لايزاد على أخذ الحقوق من الظالم كسائر الحقوق. 2. القول الثاني: أن الزكاة تؤخذ منه ويعزر بأخذ شطر ماله، وهو قول الشافعي في القديم، 51 وإحدى

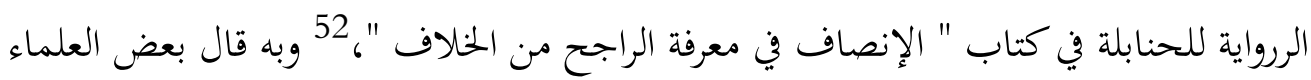

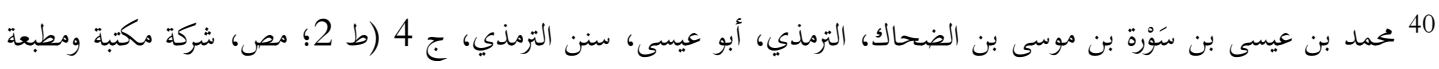
مصطفى البابي الحلبي، 1395 هـ / 1975 م) ص صـ 162.

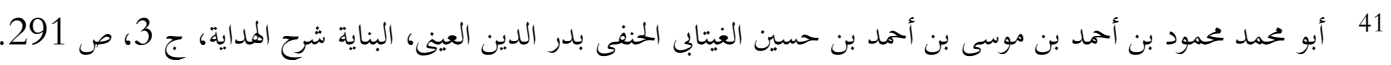

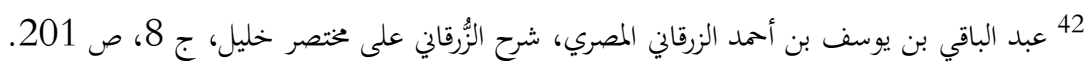

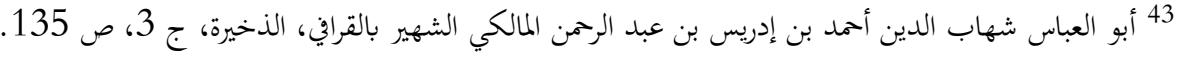

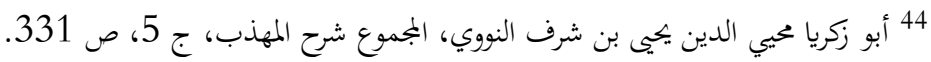

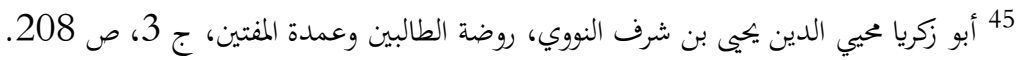

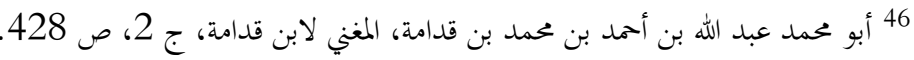

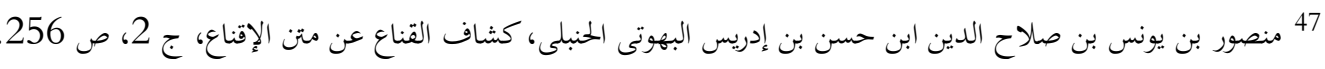

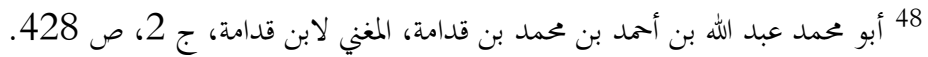

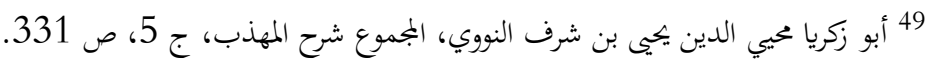

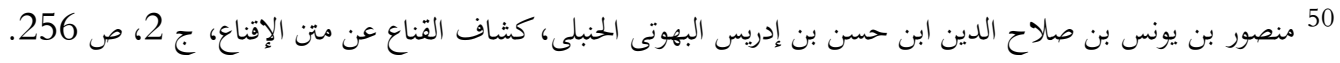

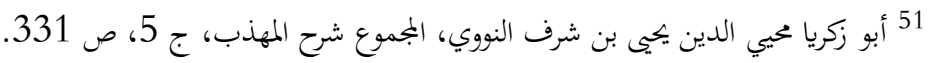

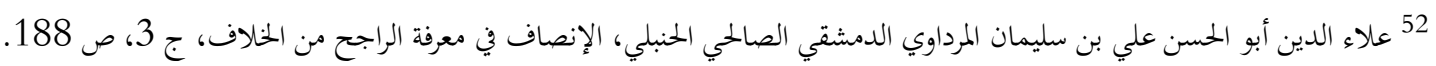


البصيرة: مجلة الاراسات الإسلامية

AL-BASHIRAH: JOURNAL OF ISLAMIC STUDIES

Vol. 2 No. 2 (2020): 186-206

ISSN: $2807-2170$

Website: https://journal.stiba.ac.id

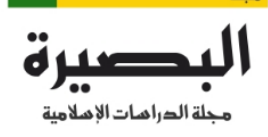

AL-BASHIRAH

كالأوزاعي وإسحاق بن راهوية في "حاشية ابن القيم مع عون المعبود"، 53 وابن العثيمين في "

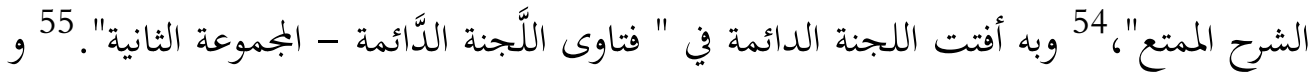
دليل على القول الثاني، وهو: عن بهزِ بنِ حكيمٍ، عن أبيه عن جلدِّه أن رسولَ الله صلَّلى الله عليه وسلم قال: الي كُِّّ سائمةِ إبلٍ في أربعين بنتُ لبون، لا تُفرَّق إبلٌٌ عن حسابها، مَنْ أعْطاها

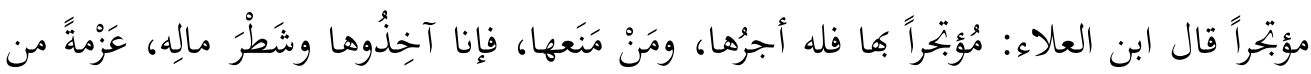

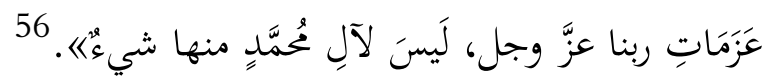
وسبب الاختلاف: التعارض والترجيح بين الأدلة. ليس في المال حق سوى الزكاة ولاهما عبادة فلا يجب بالامتناع منها أخذ شطر ماله كسائر العبادات وحديث بهز بن حكيم منسوخ فان ذلك حين كانت العقوبات في الاموال ثم نسخت وان امتنع بمنعة قاتله الامام لان أبا بكر الصديق رضي الله عنه قاتل مانعي الزكاة.

واللطيفة من هذا الخلاف أن لكل مذهب له دليل الذي يستدل به فينبغي للمسلم أن يتعاذر في هذا الخلاف ولا يكون هذا الخلاف سبب اختلاف وتفرق بين المسلمين لأن لاخلاف والتفرق يضيفان الأخوة.

الخاتمة أ. أهم نتائج البحث

الحمد اله الذي علم بالقلام وعلم الإنسان ما لم يعلم، بعد ما ذكر وجمع وحلل الباحث كلام علماء المذاهب الأربعة حول مسألة حكم تعزير مانع الزكاة بأخذ المال في الباب الثانى إلى الباب الرابع. و ين هذه الخاتمة سيتلخص الباحث أهم النتائج المتعلقة بمعضوع هذا البحث ، وهي كما يلي:

53 محمد أشرف بن أمير بن علي بن حيدر، أبو عبد الرممن، شرف الحق، الصديقي اشية ابن القيم مع عون المعبود، ج 4 (ط 2؛ بيروت،

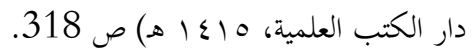

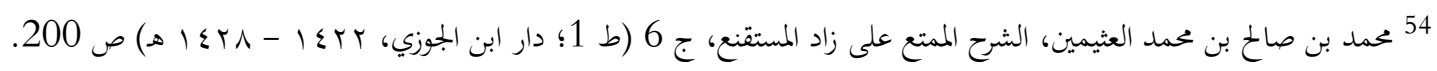

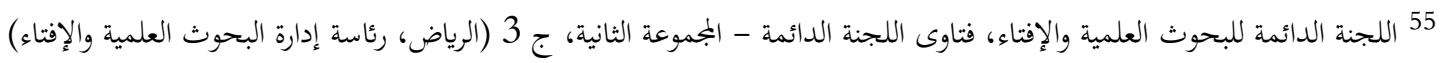

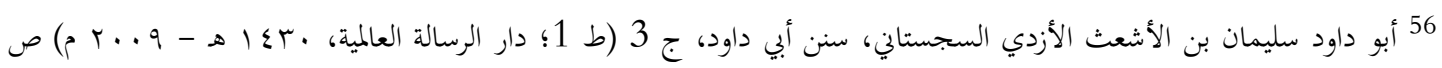


البصيرة: مجلة الاراسات الإسلامية

AL-BASHIRAH: JOURNAL OF ISLAMIC STUDIES

Vol. 2 No. 2 (2020): 186-206

ISSN: $2807-2170$

Website: https://journal.stiba.ac.id

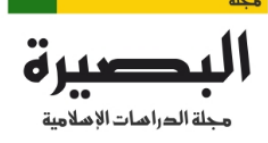

AL-BASHIRAH

1. الزكاة فرض عين على كل من توفرت فيه شروط وجوبها، وقد ثبتت فرضيتها بالكتاب والسنة

$$
\text { والإجماع، وحكم فرضها معلوم من الدين بالضرورة. }
$$

2. منع الزكاة بخلاً بها وحرصاً وجشعاً من أكبر الكبائر بالنسبة لعقوبته الأخروية وأقبح الجرائم

بالنسبة للعقوبة الدنيوية، فعلينا أن نجتنبه.

3. قد اتفق المذاهب الفقهية الأربعة على تعزير مانع الزكاة بأخذ ماله حسب ما وجب عليه

فقط دون الزيادة. بينما بعض العلماء ذهبوا إلى تعزير مانع الزكاة بأخذ ما وجب عليه مع

زيادة شطر ماله,وهذا قول الشافعي في القديم، 57 وإحدى الروواية للحنابلة في كتاب " لرئل

الإنصاف في معرفة الراجح من الخلاف "، 58 وبه قال بعض العلماء كالأوزاعي وإسحاق

بن راهوية في "حاشية ابن القيم مع عون المعبود"، 59 وابن العثيمين في " الشرح الممتع"، 60

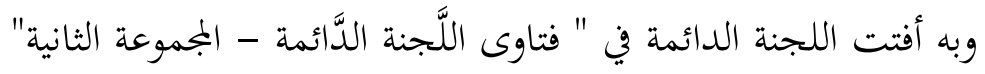

ب. فوائد البحث

ومن المبحث السابق، يعرف أنه لكل مذهب له أدلة التي احتج بها، نظرا من ذلك أن لا يكون

هذا سببا للاختالف والتفرق بين المسلمين، لأن هذه المسألة من مسائل الفرعية الجائزة التي يجوز الحلاف فيها مادام لا يفسد ولا يدخل في المسألة الأصولية فلا بأس به، لكل واحد يعمل بحجته على ما يتيقن ويطمئن فيه وأن لا تكون هذه المسألة سببا من إزالة الأخووة بين المسلمين.

هذه المسألة، فرع من العلوم الفقهية التي يبحثها الباحث من كتب العلماء خصة من علماء الحنفية والمالكية والشافعية والحنابلة وكذالك الأحاديث التي أخذناها مخصصة من كتب العلماء المحدثين المعتبرين بالكتاب السنة، ولذا يكون هذا البحث حبث منحصر.

فمن رغب في معرفة هذه المسألة على وجه العام من الحنفية والمالكية والشافعية والحنابلة فليقرأ كتب العلماء من تلك المذاهب الأربعة، فسوف يجد أن هذه مسالة واسعة. والأخير تنبيه لجميع المسلمين ألا يتوقفوا من قراءة سرية النبي صلى الله عليه وسلم ومعرفته ومعرفة سننه وأيامه، يجعل هذا زايدة في حب النبي صلى الله عليه وسلم ورجاء من مرافقته في الجنة العليا.

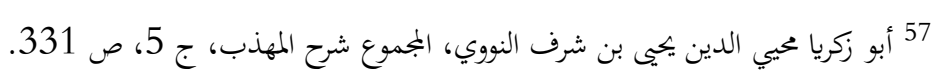

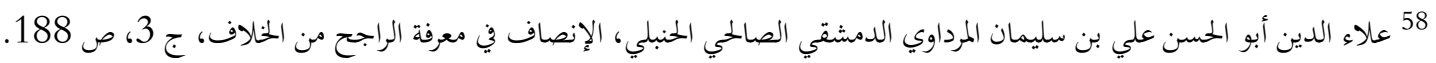

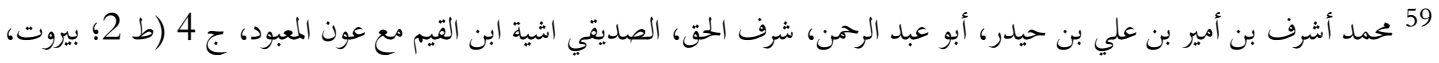

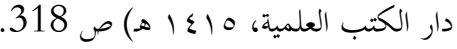

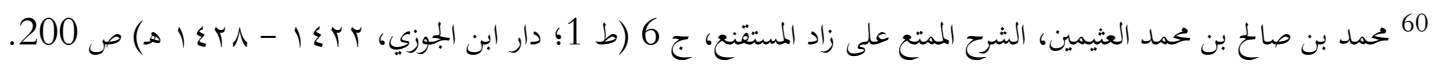




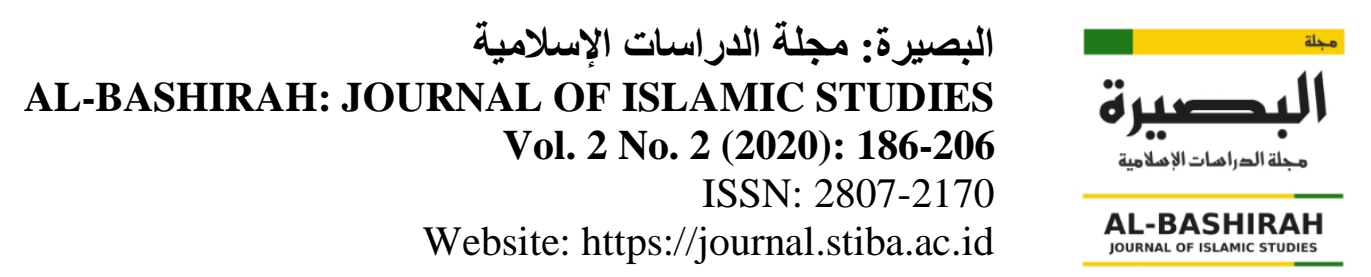

المصادر

'Abd al-Gānī al-Daqr. Ahmad bin Hanbal Imām Ahl al-Sunnah. Al-Ṭab'ah: IV. Dimasyq: Dār al-Qalam, 1999

'Abd al-Gan̄̄ al-Qadr. Al-Imām Mālik bin Anas Imām Dār al-Hijrah. Al-Ṭab'ah: III. Sūrīah: Dār al-Qalam, 1998

Abū 'abd al-Raḥmān, Muhammad Asyraf bin Amīr bin 'Alī bin Haidar. Hāsyiah Ibn al-Qayyìm 'alā 'Aun al-Ma 'būd, vol. IV. Al-Ṭab 'ah; II. Bīrūt: Dār al-Ktub al'Ilmīah, 1994

Abū al-Barakāt 'Abdullāh bin Aḥmad bin Mạ̣mūd Ḥāfiz al-Dīn al-Nasafī. Kanz alDaqū'iq. Al-Ṭab 'ah: I. Dār al-Basyā'ir al-Islāmīah, 2011

Abū al-Barakāt 'Abdullāh bin Aḥmad bin Maḥmūd Ḥāfiz al-Dīn al-Nasafî. Kanz alDaqū'iq. Al-Ṭab 'ah: I. Dār al-Basyā'ir al-Islāmīah, 2011

Abū al-Ḥusain, Muslim bin al-Hajjāj al-Qusyairī al-Naisābūrī. Șah̄̄h Muslim, vol. II. Al-Ṭab 'ah: I. Al-Qāhirah: Dār Ihyā’’ al-Kutub al- 'Arabīah, dūna sanah

Abū Dāwūd, Sulaimān bin al-Asy'aś al-Azdī al-Sijistānī. Sunan Abī Dāwūd, vol. III. Al-Ṭab 'ah; I. Dār al-Risālah al- 'Ālamīah, 2009

Abū Mālik Kamāl bin as-Sayyid Sālim. Șaḥịh Fiqh al-Sunnah wa Adillatuh wa Taud̄ịh Mażāhib al-A'immah. Al-Ṭab'ah: I. Al-Qāhirah: Al-Maktabah Dār alTaufIqīah, 2003

Aḥmad Mukhtār 'Abd al-Ḥamīd 'Umar. Mu 'jam al-Lugah al- 'Arabīah al-Mu 'ạșirah, vol. II. Al-Ṭab'ah; I. 'Ālam al-Kutub, 2008

Al-Aṣbahāni, Abū Nu'aim Aḥmad bin 'Abdillāh bin Aḥmad bin Isḥāq bin Mūsā bin Mahrān. Hilyah al-Auliyā' wa Tabaqāt al-Asfiyā', vol. IX. Al-Ṭab'ah; I. Bijiwār Muhạaazah Miṣr, 1974

Al-Baihaqī̄, Abū Bakr Aḥmad bin al-Ḥusain. Manāqib al-Syāfi ‘̀ , vol. I. Al-Ṭab 'ah; I. Al-Qāhirah: Maktabah Dār al-Turās̀, 1970

Al-Baihaqī, Abū Bakr. Al-Sunan al-Kubrā, vol. IV. Al-Ṭab 'ah: III. Bīrūt: Dār al-Kutub al-'Ilmīah, 2003

Al-Buhūtī, Manșūr bin Yūnus bin Șalāḥ al-Dīn ibn Hasan bin Idrīs. Kasysyāf alQannā' 'an Matn al-Iqnā', vol. II. Al-Ṭab'ah; I. Dār al-Ktub al- 'Ilmīah, dūna sanah

Al-Buhūtī, Manșūr bin Yūnus. Al-Rauḍ al-Murbi ' bī Syarh Zād al-Mustaqni Mukhtașar al-Muqni ', vol. I. Al-Ṭab 'ah: I. Al-Kuwait: Dār Rakā'iz, 2016

Al-Bukhārī, Muḥammad bin Ismā' īl. Șaḥịh al-Bukhārī. Al-Qāhirah: dār al-ḥadì̀, 2004 


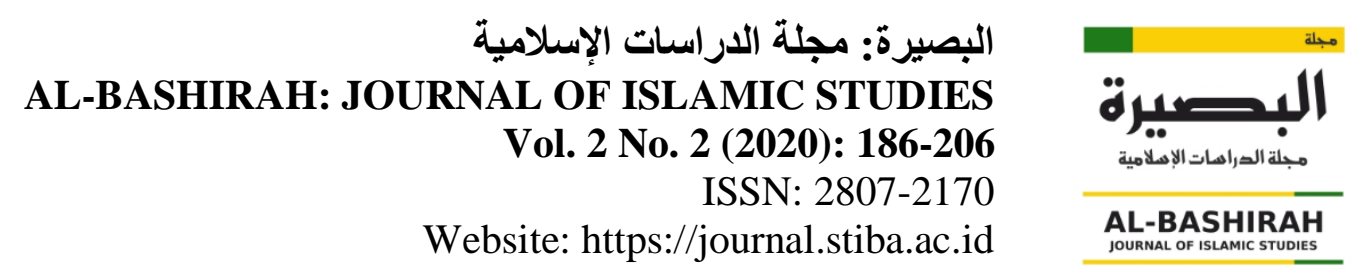

Al-Dārimī, Abu Muhammad 'Abdullāh bin 'Abd al-Raḥmān. Sunan al-Dārimī, vol. II. Al-Ṭab 'ah: I. Al-Mamlakah al- 'Arabīah al-Su ūdīah: Dār al-Mugnī li anNasyr wa al-Tauzī', 2000

Al-Hikmah min Masyrū ìah al-Zakāh, Mausū 'ah al-Fiqh al-Islāmī vol. III. Al-Ṭab ah: I. Bait al-Afkār al-Duwalīah, 2009

'Alī Jum 'ah Muḥammad 'Abd al-Wahhāb, Muftī al-Diyār al-Mișrīah. Al-Madkhal ilā Dirāsah al-Mażāhib al-Fiqhīah. Al-Ṭab'ah: II. Al-Qāhirah: Dār al-Salām, 2001

Al-Imām Aḥmad bin Hanbal. Musnad al-Imām Ahmad bin Hanbal, vol. XXIII. AlȚab 'ah: I. Mu'assasah al-Risālah, 2001

Al-Jurjānī, 'Alī bin Muḥammad bin 'Alī al-Zain al-Syarīf. Al-Ta 'rīfāt. Al-Ṭab ah; I. Bīrūt: Dār al-Kutub al- 'Ilmīah, 1983

Al-Kāsānī, Abū Bakr. Badā' 'i al-Șanā' 'i fì Tartīb al-Syarā' 'i , vol. II. Al-Ṭab ah: II. Dār al-Kutub al-'Ilmīah, 1986

Al-Lajnah al-Dā'imah lī al-Buhūis al-'Ilmīah wa al-Iftā'. Fatāwā al-Lajnah alDā'imah-Al-Majmū'ah al-s̄āniah, vol. III. Al-Ṭab'ah; I. Al-Riyāḍ: Ri'āsah Idārah al-Buhūis al-'Ilmīah wa al-Iftā', dūna sanah

Al-Māwardī, Abū al-Ḥasan 'Alī bin Muḥammad bin Muḥammad bin Habīb al-Bașrī al-Bagdādī. Al-Aḥkām al-Sulțānīah. Al-Ṭab 'ah; I. Dār al-Ḥadī̀, dūna sanah

Al-Nasā'̄̄, Abū 'Abd al-Raḥmān Aḥmad bin Syu'aib bin 'Alī al-Khurāsān̄̄. Al-sunan

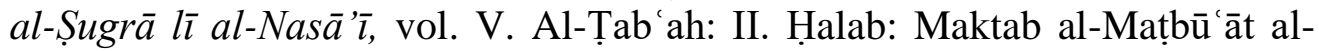
Islāmīah, 1986

Al-Nawawī, Abū Zakarīa Muhyī al-Dīn bin Syaraf. Al-Majmū' Syarh al-Muhażżab, vol. V. Al-Ṭab ah: I. DImasyq: Dār al-Fikr, dūna sanah

Al-Nawawī, Abū Zakarīa Muhyȳ al-Dīn Yahyā bin Syaraf. Kasysyāf al-Qannāa wa 'Umdah al-Muftīn, vol. III, dūna țab'ah

Al-Qaț̣ān, Mannā' bin Khalīl. Tārīkh al-Tasyrī‘ al-Islāmī. Al-Ṭab'ah; V. Maktabah Wahbah, 2001

Al-Qur'ān al-Karīm

Al-Qurāfî, Abū al-'Abbās Syihāb al-Dīn Aḥmad bin Idrīs bin 'Abd al-Raḥmān alMālikī.

Al-Rāzī, Muḥammad bin Abī Bakr bin 'Abd al-Qādir al-Ḥanafī. Mukhtār al-Ṣihạḥ. Al-Ṭab 'ah: V. Bīrūt: Al-Maktabah al- 'Așrīah, 1999

Al-Ṣan 'ānī, Abū Bakr 'Abd al-Razzāq. Al-Mușannaf, vol. II. Al-Ṭab 'ah: II. Bīrūt: AlMaktab al-Islāmīi, 1983

Al-Ṣan ānī, Muḥammad bin Ismā'̄̄l bin al-Amīr al-Yaman̄̄. Subul al-Salām Syarh Bulūg al-Marām fì Adillah al-Aḥkām, vol. II. Al-Ṭab 'ah: I. Miṣr: Maktabah alİmān al-Manșūrah, dūna sanah

$$
\text { مكران عثمان, عمران بخارى,أول رفاعي وهاب , أريس فردوس, حكم تعزير مانع الزكاة... }
$$




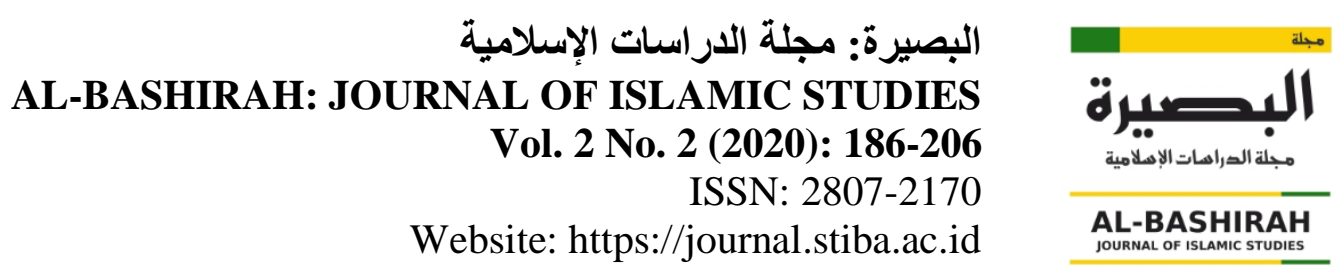

Al-Suyūṭ̂̄, Jalāl al-Dīn 'Abd al-Raḥmān. Al-Asybāh wa Al-Nazā'ir fì Qawā id wa Furū' Fiqh al-Syāfi 'ìah. Al-Ṭab 'ah: I. Dār al-Kutub al- 'Ilmīah, 1983

Al-Ṣyaukān̄i, Muḥammad bin 'Alī bin Muḥammad bin 'Abdillāh. Nail al-Auṭār, vol. IV. Al-Ṭab 'ah: I. Miṣr: Dār al-Ḥad̄ìs, 1993

Al-Ṭayyār, 'Abdullah bin Muḥammad wa Zumalā'uh. Al-fiqh al-Muyassar. AlṬab ah: II. Al-Riyāḍ: Madār al-Waṭn lī al-Nasyr, 2012

Al-Tirmiżī, Muḥammad bin 'Īsā bin Saurah bin Mūsā bin al-Ḍaḥhāk. Sunan al-Tirmiż̄̄, vol. IV. Al-Ṭab 'ah; II. Miṣr: Syarikah Maktabah wa Maṭba 'ah Muștafā al-Bābī al-Ḥalabī, 1975

Al-Tuwaijirī, Muḥammad bin Ibrāhīm bin 'Abdillāh. Mausū 'ah al-Fiqh al-Islāmī, vol. I. Al-Ṭab 'ah: I. Bait al-Afkār al-Duwalīah, 2009

Al- 'Umari, 'Īsā. Fiqh al- 'Uqūbāt fì al-Syarī'ah al-Islāmīah. Al-Ṭab'ah: II. AlQāhirah: Dār al-Haramain, 2010

Al-'Us̉aimīn, Muhammad bi Șāliḥ bin Muhammad. Majmū' Fatāwā wa Rasā'il Faḍ̂lah al-Syakh Muhammad bin Ṣāliḥ al- 'Uśaimīn, vol. XVIII. Al-Ṭab'ah: I. Dār al-Waṭn, 2004

Al- 'Us̉aimīn, Muḥammad bin Șāliḥ bin Muhammad. Al-Syarḥ al-Mumti' 'alā Zād alMustaqni ', vol. VI. Al-Țab'ah; I. Dār Ibn al-Jauzī, 2007

Al-żahabī, Syams al-Dīn Abū 'Abdillah Muḥammad bin Aḥmad. Siyar A 'lām alNubalā', vol. VIII. Al-Ṭab 'ah; III. Mu'assasah al-Risālah, 1985

Al-żakhīrah, vol. III. Al-Ṭab 'ah; I. Bīrūt: Dār al-Garb al-Islāmī, 1994

Al-Zarqānī al-Miṣrī, 'Abd al-Bāqī bin Yūsuf bin Aḥmad. Syarh al-Zurqān̄̄ 'alā Mukhtașar Khalīl, vol. VIII. Al-Țab 'ah; I. Bīrūt: Dār al-Ktub al-'Ilmīah, 2002

Al-Zuhailī, Wahbah bin Mușțafā. Al-Fiqh al-Islāmī wa Adillatuh, vol.VII. AlTab 'ah: IV. Sūrīah: Dār al-Fikr, Dūna sanah

Badr al-Dīn al- 'Ain̄i, Abū Muḥammad Mạ̣mūd bin Aḥmad bin Mūsā bin Aḥmad bin Husain al-Gītābī al-Hanafì. Al-Bināyah Syarḥ al-Hidāyah, vol. III. Al-Tab ah; II. Bīrūt: Dār al-Kutub al-'Ilmīah, 2000

Bakr Muḥammad Ibrāhīm. Al-Imām al-Syāfi ‘̀ Hayātuh wa Fiqhuh. Al-Ṭab'ah: I. Markaz al-Rāyah lì al-Nasyr al-I' lām, 2007

Ibn 'Abd al-Bārr al-Qurțubī, Abū 'Umar Yūsuf bin 'Abdillāh bin Muhammad. AlIntifā' fì Fad̄à'il al-salāsah al-A'immah al-Fuqahā' Mālik wa Al-Syāfi 'ì wa Abī Hanīfah Rad̄iallāh 'Anhum. Al-Ṭab'ah; I. Bīrūt: Dār al-Kutub al- 'Ilmīah, dūna sanah

Ibn 'Abd al-Bārr al-Qurțubī, Abū 'Umar Yūsuf bin 'Abdillāh bin Muhammad. AlIntifā' fì Faḍa 'il al-salāsah al-A 'immah al-Fuqahā' Mālik wa Al-Syāfi 'ì wa Abì Hanīfah Rậīallāh 'Anhum. Al-Ṭab'ah; I. Bīrūt: Dār al-Kutub al- 'Ilmīah, dūna sanah 


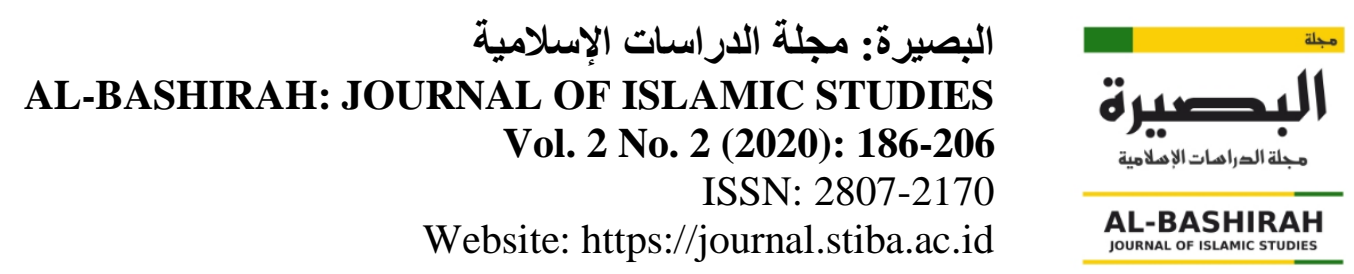

Ibn 'Abd al-Barr, Abū 'Umar Yūsuf bin 'Abdillah bin Muhammad. Al-Istiżkār, vol. II. Al-Ṭab 'ah; II. Bīrūt: Dār al-Kutub al- 'Ilmīah, dūna sanah

Ibn 'Abd al-Barr, Abū 'Umar Yūsuf bin 'Abdillah bin Muhammad. Al-Istiżkār, vol. II. Al-Ṭab 'ah; II. Bīrūt: Dār al-Kutub al- 'Ilmīah, dūna sanah

Ibn Abī Syaibah, Abū Bakr. Al-Muṣannaf fì al-Ahāadìì wa al-Āṣār, vol. III. Al-Ṭab 'ah: I. Al-Riyạ̣̄: Maktabah al-Rusyd, 1988

Ibn al-Jauz̄i Abū al-Faraj, Jamāl al-Dīn. Manāqib al-Imām Aḥmad. Al-Ṭab 'ah; II. Dār Hijr, 1988

Ibn al-Jauzī Abū al-Faraj, Jamāl al-Dīn. Manāqib al-Imām Ahmad. Al-Ṭab 'ah; II. Dār Hijr, 1988

Ibn Batțāl, Abū al-Hasan 'Alī bin Khalaf bin 'Abd al-Malik. Syarh Ṣaḥ̄h al-Bukhārī lī Ibn Battāl, vol. III. Al-Ṭab 'ah; II. Al-Riyāḍ: Maktabah al-Rusyd, 2003Ibn Hajar al-Haitamī, Aḥmad bin Muhammad bin 'Alī. Tuḥfah al-Muḥtāj fì Syarh al-Minhāj, vol.I. Al-Ṭab ah: I. Miṣr: Al-Maktabah al-Tijārīah, 1983

Ibn Batțāl, Abū al-Hasan 'Alī bin Khalaf bin 'Abd al-Malik. Syarh Șaḥ̄h al-Bukhārī lī Ibn Batṭāl, vol. III. Al-Ṭab ah; II. Al-Riyāḍ: Maktabah al-Rusyd, 2003

Ibn Hajar al- 'Asqalānī, Abū al-Fạ̣l Aḥmad bin 'Alī. Fatḥ al-Bārī Syarh Ṣah̄ịh alBukhārī, vol. III. Al-Ṭab'ah; I. Bīrūt: Dār al-Ma rifah, dūna sanah

Ibn Ḥajar al- 'Asqalānī, Abū al-Fạ̣l Aḥmad bin 'Alī. Fatḥ al-Bārī Syarḥ Sạhīh alBukhārī, vol. III. Al-Ṭab'ah; I. Bīrūt: Dār al-Ma rifah, dūna sanah

Ibn Jarīr al-Ṭabarī, Abū Ja far Muhammad. Jāmi al-Bayān 'an Ta'wūl Āi al-Qur'ān, vol. II. Al-Ṭab'ah: I. Makkah al-Mukarramah: Dar al-Tarbiah wa al-Turāś, dūna sanah

Ibn Manzūur, Muhammad bin Makram bin 'Alī. Lisān al- 'Arab, vol. XIV. Al-Ṭab ah: III. Bīrūt: Dār Șādir, 1993

Ibn Qudāmah al-Maqdis̄̄, Abū Muḥammad 'Abdullāh bin Aḥmad bin Muhammad. AlMugnī lī Ibn Qudāmah, vol. II. Al-Ṭab 'ah: I. Maktabah al-Qāhirah, 1968

Ibn Qudāmah al-Maqdisī, Muwaffaq al-Dīn Abū Muḥammad 'Abdullāh bin Aḥmad bin Muḥammad. Al-Mugnī, vol. IV. Al-Ṭab'ah: III. Al-Riyāḍ: Dār Ālam alKutub, 1997

Ibn Rusyd al-Qurțubī, Abū al-Walid Muḥammad bin Aḥmad. Bidāyah al-Mujtahid wa Nihāyah al-Muqtașid, vol. II. Al-Ṭab ah: I. Al-Qāhirah: Dār al-Ḥadīṣ, 2004

Ibn Taimīah, Taqī al-Dīn Abū al- 'Abbās Aḥmad bin 'Abd. Al-Ḥalīm. Majmū' alFatāwā, vol. XXV. Al-Ṭab'ah: I. Al-madīnah al-Nabawīah: Majma' al-Malik Fahd lī Ṭibā'ah al-Muṣhaf al-Syarīf, Dūna sanah

Jamā'ah min al-'Ulamā'. Al-Mausū'ah al-Fiqhīah al-Kuwaitīah, vol. XXIII. AlKuwait: Wizārah al-Auqāf wa al-Syu ūn al-Islāmīah, 1983-2006 


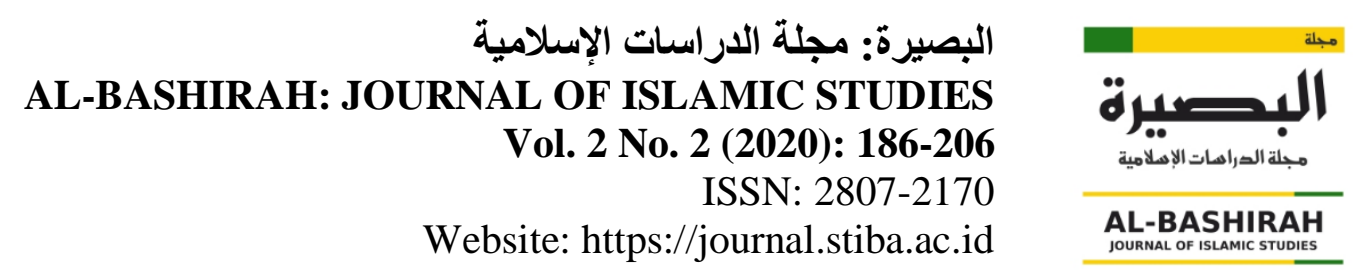

Maḥmūd Muḥammad Khalīl. Al-Musnad al-Jāmi`. Al-Ṭab'ah: I. Bīrūt: Dār al-Jaīl, 1992

Majmū'ah min al-Mu'allifīn. Mausū'ah al-Ijmā' fì al-Fiqh al-Islāmī, vol. IX. AlṬab 'ah; I. Al-Riyāẹ: Dār al-Faḍīlah, 2012

Muḥammad bin Aḥmad 'Arafah al-Dasūqī al-Mālikī. Hāasyiah al-Dāsūq̄i 'alā al-Syarh al-Kabīr, vol. I. Al-Ṭab ah: I. Dār al-Fikr

Muḥammad bin 'Alawī al-Malikī al-Husan̄i, Imām Dār al-Hijrah Mālik bin Anas. Al-Ṭab 'ah: II. Bīrūt: Dār al-Kutub al-'Ilmīah, 2010

Muștafā al-Syak'ah. Al-A'immah al-Arba 'ah, vol. IV. Al-Ṭab 'ah; III. Bīrūt: Dār alKitāb al-Lubnān̄̄, 1991

'Umar bin 'Abd al-'Azīz al-Gudyān. Tārīkh al-Fiqh. Al-Ṭab'ah; I. Al-Mamlakah al'Arabīah al-Su'ūdīah: Wizārah al-Ta' līm Jāmi'ah al-Imām Muhammad bin Su'ūd al-Islāmīah, dūna sanah

'Umar Sulaimān al-Asyqār. Al-Madkhal Dirāsah al-Madāris al-Mas̄āhib al-Fiqhīah. Al-Ṭab 'ah; II. Al-Quds: Dār al-Nafā' is, 1998

Wahbī Sulaimān Gāwjī. Abū Hanīfah al-Nu 'mān Imām al-A'immah al-Fuqahā. AlȚab'ah: V. Dār al-Qalam, 1992

Wizārah al-Auqāf wa al-Syu'ūn al-Islāmīah. Al-Mausū 'ah al-Fiqhīah al-Kuwaitīah, vol. XXIII. Al-Ṭab'ah: II. Al-Kuwait: Dār al-Salāsil, dūna sanah

Zain al-Dīn bin Ibrāhīm ibn Nujaim. Al-Baḥr al-Rā'iq Syarḥ Kanz al-Daqā 'iq, vol. II. Al-Ṭab ah: II. Dār al-Kutub al-Islāmī, 2018 